\title{
Archeological Site Assesments and Survey at Aquilla Lake, Hill County, Texas
}

Aaron R. Norment

AmaTerra Environmental, Inc.

Karl W. Kibler

Cross Timbers Geoarcheological Services

Amy E. Dase

Prewitt and Associates, Inc.

Follow this and additional works at: https://scholarworks.sfasu.edu/ita

Part of the American Material Culture Commons, Archaeological Anthropology Commons, Environmental Studies Commons, Other American Studies Commons, Other Arts and Humanities Commons, Other History of Art, Architecture, and Archaeology Commons, and the United States History Commons

Tell us how this article helped you.

This Article is brought to you for free and open access by the Center for Regional Heritage Research at SFA ScholarWorks. It has been accepted for inclusion in Index of Texas Archaeology: Open Access Gray Literature from the Lone Star State by an authorized editor of SFA ScholarWorks. For more information, please contact cdsscholarworks@sfasu.edu. 


\section{Archeological Site Assesments and Survey at Aquilla Lake, Hill County, Texas}

Creative Commons License

(c) (i) ()

This work is licensed under a Creative Commons Attribution-NonCommercial-No Derivative Works 4.0 International License. 


\section{ARCHEOLOGICAL SITE ASSESSMENTS AND SURVEY AT AQUILLA LAKE, HILL COUNTY, TEXAS}

by

Aaron R. Norment

Karl W. Kibler

and

Amy E. Dase

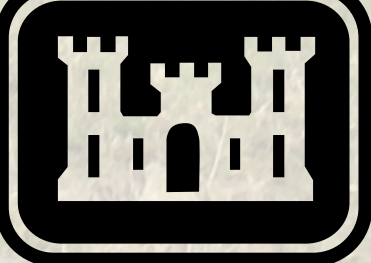

US Army Corps

of Engineers

Fort Worth District

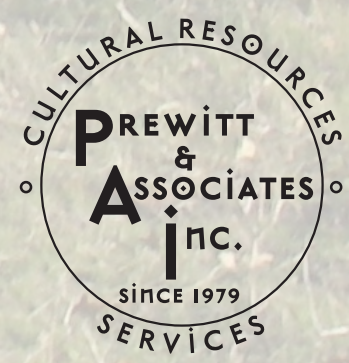




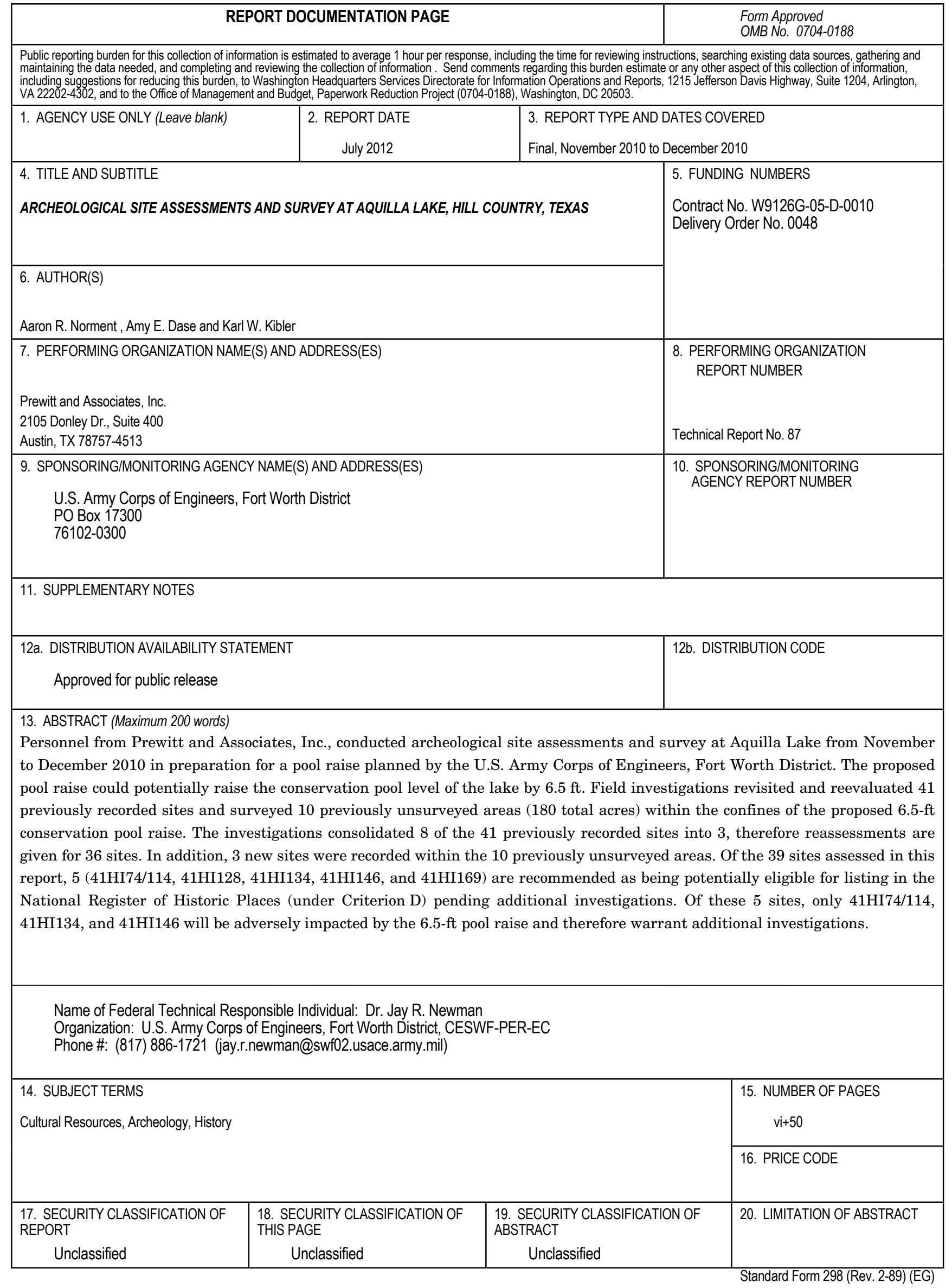




\title{
ARCHEOLOGICAL SITE ASSESSMENTS AND SURVEY AT AQUILLA LAKE, HILL COUNTY, TEXAS
}

\author{
by \\ Aaron R. Norment \\ Amy E. Dase \\ and \\ Karl W. Kibler \\ Principal Investigator: Karl W. Kibler
}

TECHNICAL REPORT NO. 87

submitted to
U.S. Army Corps of Engineers
Fort Worth District

\begin{abstract}
by
Prewitt and Associates, Inc. Cultural Resources Services Austin, Texas
\end{abstract}

PAI No. 210032 



\section{TABLE OF CONTENTS}

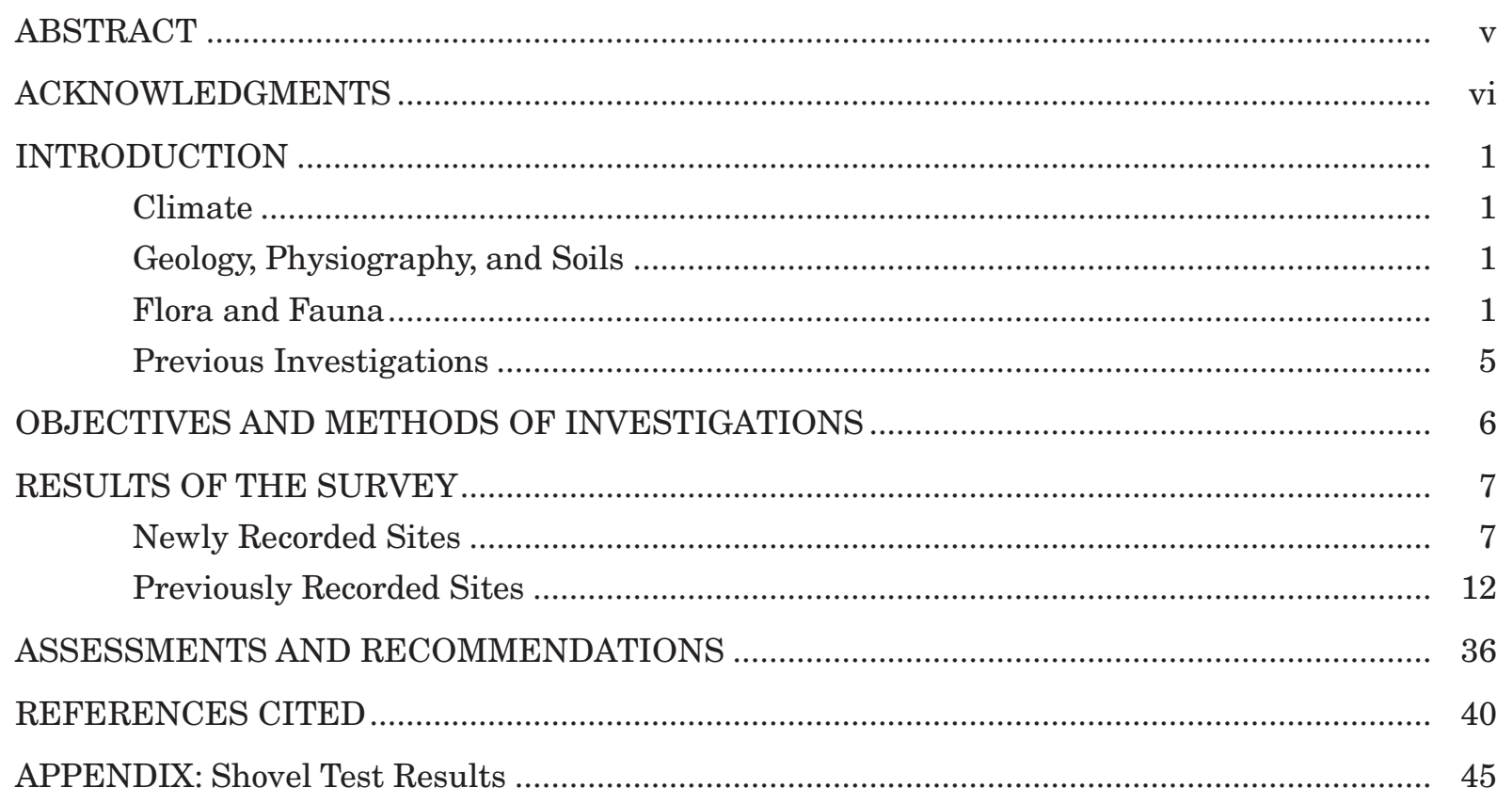




\section{LIST OF FIGURES}

1. Project area location map showing proposed 6.5-ft pool elevation raise ........................... 2

2. Previously recorded sites and previously unsurveyed areas within the project area......... 3

3. View of Cross Timbers environment within the project area............................................. 4

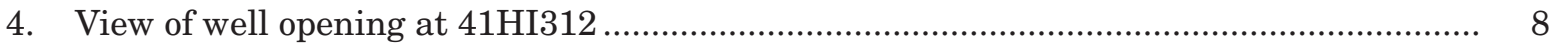

5. In 1938 the farm had a house, related domestic outbuildings, several large agricultural outbuildings, clearly indicated fence lines for livestock operations,

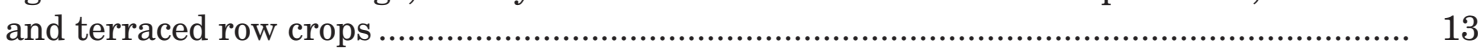

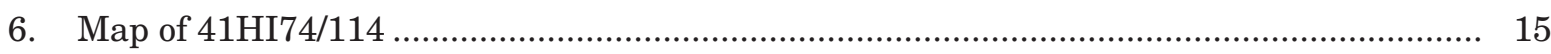

7. View of beach gravels deposited by wave action within 41HI109/110 _.......................... 19

8. View of lithic debitage among beach gravels within 41HI109/110 .................................. 19

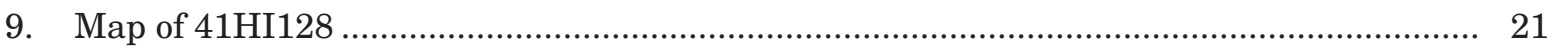

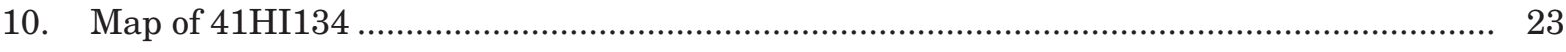

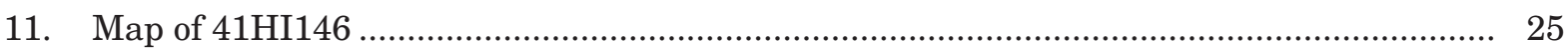

12. View of erosion within 41HI150-153, typical of most sites along the lake margins.......... 27

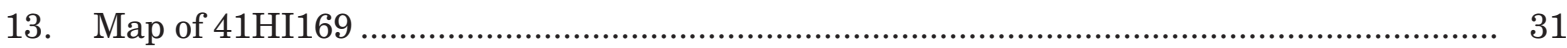

\section{LIST OF TABLES}

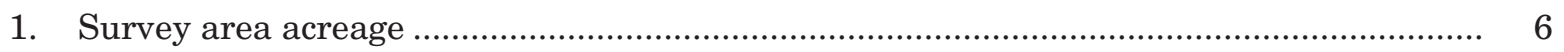

2. Summary of site assessments for 39 archeological sites at Aquilla Lake ........................ 37

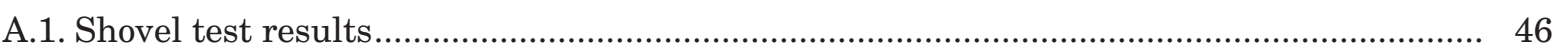




\begin{abstract}
Personnel from Prewitt and Associates, Inc., conducted archeological site assessments and survey at Aquilla Lake from November to December 2010 in preparation for a pool raise planned by the U.S. Army Corps of Engineers, Fort Worth District. The proposed pool raise could potentially raise the conservation pool level of the lake by $6.5 \mathrm{ft}$. Field investigations revisited and reevaluated 41 previously recorded sites and surveyed 10 previously unsurveyed areas (180 total acres) within the confines of the proposed 6.5 -ft conservation pool raise. The investigations consolidated 8 of the 41 previously recorded sites into 3, therefore reassessments are given for 36 sites. In addition, 3 new sites were recorded within the 10 previously unsurveyed areas. Of the 39 sites assessed in this report, 5 (41HI74/114, 41HI128, 41HI134, 41HI146, and 41HI169) are recommended as being potentially eligible for listing in the National Register of Historic Places (under Criterion D) pending additional investigations. Of these 5 sites, only 41HI74/114, 41HI134, and 41HI146 will be adversely impacted by the 6.5 -ft pool raise and therefore warrant additional investigations.
\end{abstract}




\section{ACKNOWLEDGMENTS}

The successful completion of this project is due in part to several key personnel at Prewitt and Associates, Inc., and the U.S. Army Corps of Engineers, Fort Worth District. The field crew consisted of project archeologist Aaron R. Norment and archeologists Matt Carter and Tess Noble. The professionalism and dedication of this crew never faltered, even during inclement weather and "roiling seas" on Aquilla Lake. Karl W. Kibler served as principal investigator. Sandra L. Hannum, along with Rob Thrift, skillfully drafted the figures for this report, and Elaine Robbins edited it.

Dr. Jay R. Newman of the U.S. Army Corps of Engineers, Fort Worth District, oversaw the project and procured funding, provided Corps site data and maps, coordinated the schedule, and provided report comments. 


\section{INTRODUCTION}

Personnel from Prewitt and Associates, Inc., conducted archeological site assessments and survey at Aquilla Lake from November 1 to December 17, 2010, in preparation for a pool raise planned by the U.S. Army Corps of Engineers, Fort Worth District (Figures 1 and 2). The proposed pool raise could potentially raise the conservation pool level of the lake by $6.5 \mathrm{ft}$. Field investigations revisited and reevaluated 41 previously recorded sites and surveyed 10 previously unsurveyed areas (180 total acres) within the confines of the proposed 6.5-ft conservation pool raise. The investigations consolidated 8 of the 41 previously recorded sites into 3 , therefore reassessments are given for 36 sites. In addition, 3 new sites were recorded within the 10 previously unsurveyed areas.

Field investigations were performed in accordance with the provisions of the Secretary of the Interior's Standards and Guidelines for Archeology and Historic Preservation (48 FR 44716-42) and Section 106 of the National Historic Preservation Act of 1966, as amended (P.L. 96-515); the National Environmental Policy Act of 1969 (P.L. 90-190); the Archeological and Historical Preservation Act of 1974 (P.L. 93-291); and Executive Order No. 11593 ("Protection and Enhancement of the Cultural Environment").

This report presents the results of these investigations. The first section provides environmental background information on the climate, geology, geomorphology, and flora and fauna of the area. A brief summary of the previous investigations conducted in the Aquilla Lake area are also provided. The next section discusses the objectives and methods of investigation. The following section presents the results of the investigations. The final section provides assessments and recommendations for the sites investigated during this project. An appendix presents the results of shovel tests excavated onsite and offsite.

\section{Climate}

The climate of north-central Texas is humid subtropical, with hot summers and mild continental-influenced winters. The winter mean daily temperature is around $47^{\circ} \mathrm{F}$, with an average daily minimum temperature around $36^{\circ} \mathrm{F}$. During the hot summers, temperatures average $83^{\circ} \mathrm{F}$ daily, and the average daily maximum temperature is $95^{\circ} \mathrm{F}$. Annual precipitation for the area averages $86.36 \mathrm{~cm}$ (34 inches), with the majority falling as rain in the spring and summer months. Winds prevail from the south throughout the year except for incursions of arctic air masses during the winter (Brooks 1978:2; Natural Fibers Information Center 1987:239-240).

\section{Geology, Physiography, and Soils}

Hill County is in a region where three major physiographic provinces converge: the Grand Prairie, the Blackland Prairie, and the Eastern Cross Timbers. Geologically, the Grand Prairie rests on a western band of Lower Cretaceous hard limestone, while the underlying bedrock of the Blackland Prairie is composed of Upper Cretaceous marls and chalks (Hill 1900:65-72). The difference is expressed in the flat terrain and shallow soils of the Grand Prairie, which is in contrast to the rolling landscape and deep black calcareous soils of the Blackland Prairie. These two regions are separated by the Eastern Cross Timbers, a thin sliver of dense oak forests extending southward from the Red River to the Waco area. The Eastern Cross Timbers developed on deep sandy soils derived from the Upper Cretaceous Woodbine Formation (Hayward et al. 1996:1-7)(Figure 3).

Upper Cretaceous formations, consisting of the Woodbine Formation and the overlying Eagle Ford Group, which is comprised of the Lake Waco and South Bosque Formations, are exposed along the margins of Aquilla Lake (Barnes 1979). The Woodbine Formation is characterized by fine-grained sandstones with some clay and shale, while the Eagle Ford Group is made up of limestones and shales. Sandy and loamy soils developed on the Woodbine Formation belong to the Gasil, Konsil, and Crosstell series (Brooks 1978). Clayey soils of the Houston Black, Heiden, and Altoga series formed on the Eagle Ford Group.

\section{Flora and Fauna}

Hill County is located within the north central portion of the Texan biotic province, where the Grand Prairie meets the Eastern Cross Timbers (Blair 1950). The floral and faunal assem- 


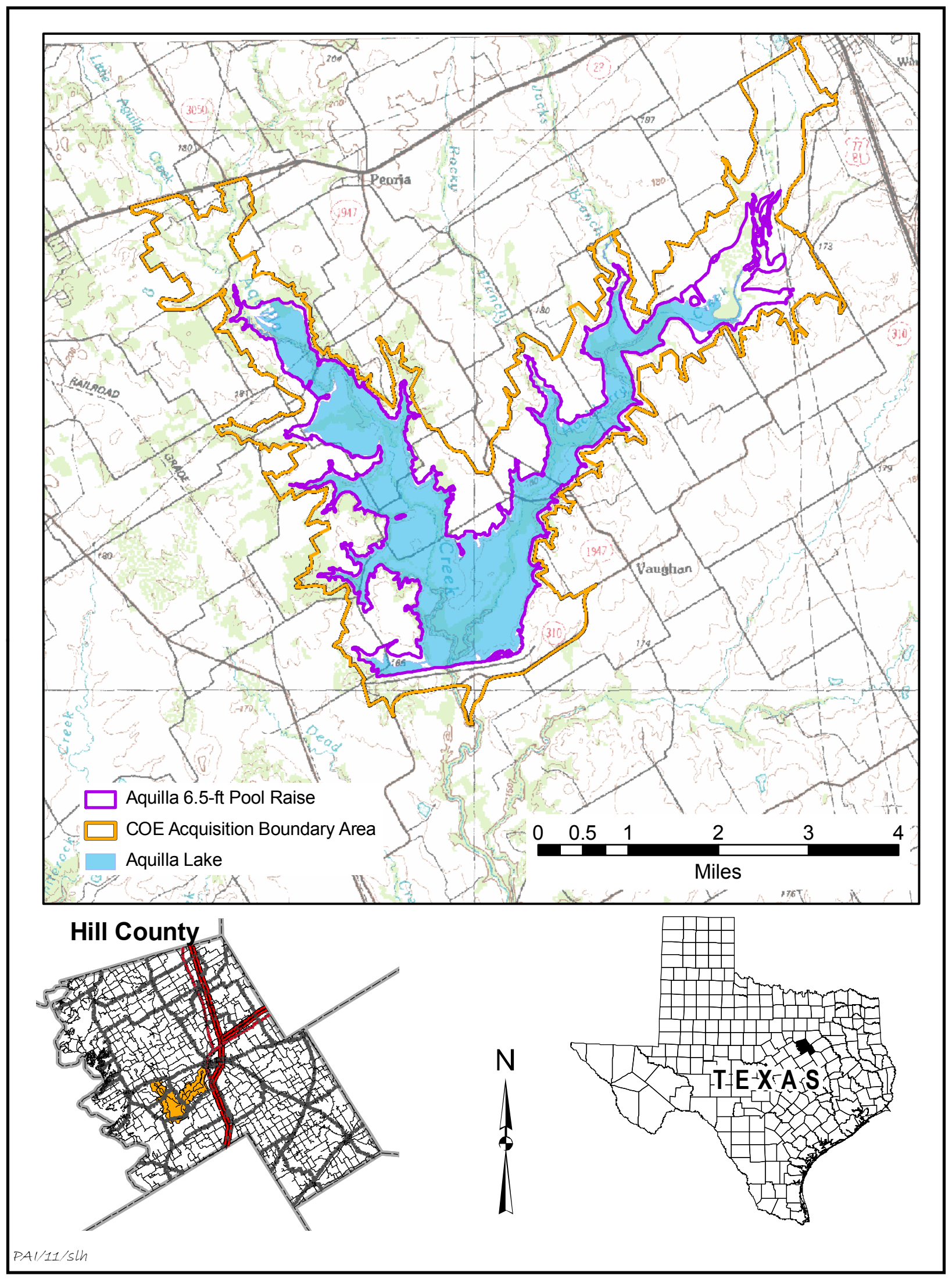

Figure 1. Project area location map showing proposed 6.5-ft pool elevation raise. 


\section{Figure Redacted}

Figure 2. Previously recorded sites and previously unsurveyed areas within the project area. 


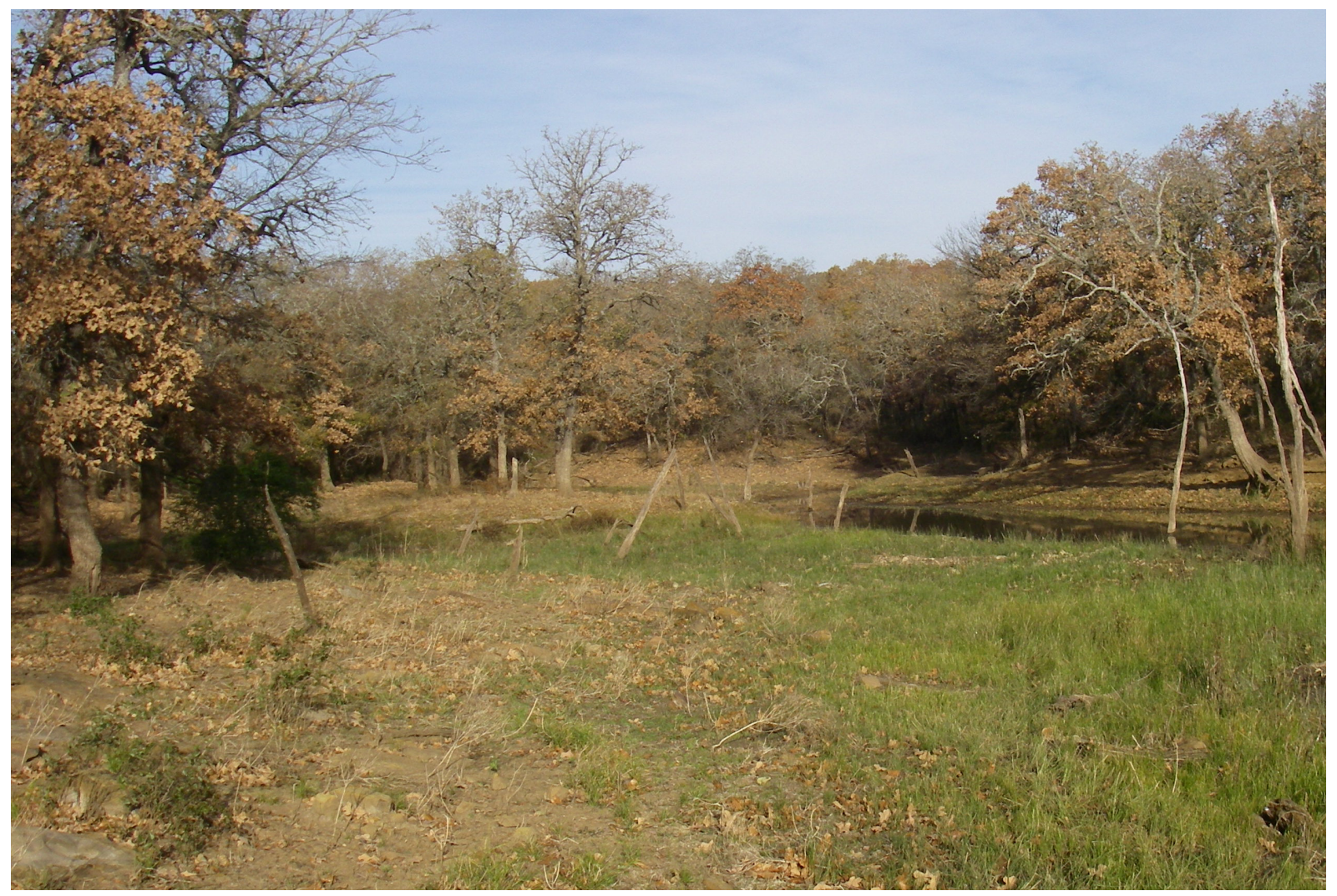

Figure 3. View of Cross Timbers environment within the project area.

blages tend to overlap with the Austroriparian province to the east, with 41 species present in both provinces. The Texan province also represents the eastern limit for several species from the west (Blair 1950:101).

Currently, much of the upland areas around Aquilla Lake are used as agricultural fields for growing cotton, sorghum, and corn. As a result, many of the native grasslands of the area have been impacted. Native grasses to the area include various bunch grasses such as buffalograss (Buchloe dactyloides), big bluestem (Andropogon gerardii), switchgrass (Panicum virgatum), and indiangrass (Sorghastrum nutans) (Austin 2011). These grasses are well adapted to the low moisture and hard silty clay soils of the prairie. Juxtaposed with the grasslands are the Eastern Cross Timbers upland forests, where sandy soils and more moisture permit dense stands of oaks (Jurney 1988:344-347). Many areas within the county are heavily wooded, with slight differences in species between the uplands and stream valleys. Common species of trees around Aquilla Lake include post oak (Quercus stellata), blackjack oak (Quercus marliandica), live oak (Quercus virginiana), juniper (Juniperus ashei), American elm (Ulmus americana), cedar elm (Ulmus crassifolia), hackberry (sugarberry) (Celtis laevigata), and bois d'arc (Maclura pomifera). Much of the original vegetation, including native grasses and oaks, has been modified as a result of modern agricultural practices (Brown 1987).

Aquilla Lake and the surrounding areas have a variety of habitats and microenvironments that support a diversity of faunal species. Present-day species include whitetail deer (Odocoileus virginianus), opossum (Didephis virginiana), raccoon (Procyon lotor), rabbits (Sylvilagus floridanus and S. aquaticus), striped skunk (Mephitis mephitis), squirrel (Sciurus sp.), coyote (Canis latrans), and turkey (Melagris gallopavo), as well as 42 other mammals, 16 species of lizards, 39 species of snakes, 5 species of urodeles, and 13 species of anurans (Blair 1959:101-102).

Previous investigations have found that other large mammals now absent from the area were utilized in prehistoric times. These include 
bison and pronghorn antelope (Brown 1987:4310 and 43-27), although bison and antelope are so rarely recovered that their influence on prehistoric diet was likely minimal. Deer was the major source of animal protein during prehistoric times (Brown 1987:43-15). Deer are found throughout the area in both the Grand Prairie and Cross Timbers.

\section{Previous Investigations}

Aquilla Lake is in the middle Brazos River valley, an area traditionally viewed as part of the central Texas archeological region (e.g., Prewitt 1981; Suhm 1960). This region is recognized based on decades of investigations at various stratified sites throughout the Edwards Plateau, its highly dissected eastern and southern margins, and the margins of physiographic regions to the east and south (see Collins [1995] for review). Aquilla Lake is on the northern periphery of the central Texas archeological region, and the archeological record and projectile point style sequences suggest influences and contacts with areas to the east and northeast (cf., Collins 1995; Johnson and Goode 1994).

An understanding of the area's archeological record has been obtained through several largescale projects, primarily reservoir salvage projects. Nearby, large-scale projects include Lake Whitney (Jelks 1953, 1962; Stephenson 1947, 1970), approximately 10 miles to the west, and Waco Lake (Collins and Holliday 1985; Duffield 1959; Mehalchick and Kibler 2008; Prikryl and Jackson 1985; Prikryl and Prewitt 1984; Story and Shafer 1965) to the south. Salvage projects at Aquilla Lake have also contributed to a fuller understanding of the archeology of the middle Brazos River valley (Brown 1987; Lynott and Peter 1977; Skinner et al. 1978; Skinner and Henderson 1972). Each of these projects has helped to establish the prehistoric cultural sequence of the area that is in use today. Generally, this cultural sequence is divided into three periods: Paleoindian, Archaic, and Late Prehistoric, and are detailed in Collins (1995), Johnson and Goode (1994), and Prewitt (1981, 1985).

The earliest known archeological investigations to occur in the Aquilla Lake area were those conducted by Frank Bryan (1930, 1931, 1937). While working as a geologist, he located six sites in the Aquilla Lake area (Brown 1987:4-2). Numerous other projects and investigations were conducted in the area, but the first formal investigations to occur at Aquilla Lake began in the early 1970s with a survey by Southern Methodist University (SMU) (Skinner and Henderson 1972). During this survey, a total of 125 prehistoric archeological sites were recorded within the proposed flood pool and alternative dam site locations. Skinner and Henderson (1972:56) concluded that the small size of the sites throughout the Aquilla Creek basin suggested that occupation was influenced by seasonally specific activities. They also suggested that groups utilizing the area probably had large and more permanent base camps elsewhere, such as along the Brazos River.

Southern Methodist University continued work in 1975 with an additional survey and the first test excavations ${ }^{1}$ (Lynott and Peter 1977). The survey focused on the finalized (and present) reservoir area and dam location. Six new sites were recorded and 68 previously recorded sites were reevaluated. Test excavations were conducted at 23 sites. Based on these excavations and previous surveys, three site types were defined within the lake area: quarries/workshops, foraging stations, and seasonal reoccupation campsites (Lynott and Peter 1977:110-112). Distinctions between the site types were based on site size, site location, artifact density, and tool diversity. Southern Methodist University continued site testing in 1977 and 1978 (Skinner et al. 1978). In total, 16 sites were tested. Data from those excavations eventually were reanalyzed and incorporated into a later mitigation report by Brown (1987).

Data recovery excavations at Aquilla Lake were carried out by the Texas Archeological Survey of the University of Texas at Austin in 1979-1980 under the direction of Richard P. Watson and again in 1982-1983 under the supervision of David O. Brown. These investigations, combined with reanalyzed data from the previous season of testing by SMU, were published as a three-volume report (Brown 1987). The report presents the results of investigations

${ }^{1}$ The site numbers used at Aquilla Lake and reported by SMU (e.g., Lynott and Peter 1977; Skinner and Henderson 1972; Skinner et al. 1978) were later changed when site trinomials were assigned by the Texas Archeological Research Laboratory (TARL). Sites mentioned and investigated in this report use the TARL site trinomials, though the old SMU site numbers are referenced where appropriate. The SMU site numbers are distinguished by an $\mathrm{x}$ that precedes the site number (e.g., x41HI99). 
at 24 sites, including a detailed prehistoric and historic research design for the central Brazos region.

Aside from investigations associated with the construction of Aquilla Lake, only a few modest archeological studies have been conducted in Hill County. Parker Nunley (1977) surveyed the proposed locations of six flood-control structures and their impoundment areas in the Aquilla Creek watershed in Hill County. No sites were recorded. James E. Warren (1977) investigated another proposed flood-retention structure and impoundment area along Little Aquilla Creek northwest of the lake. Six sites were recorded, 41HI97-41HI102. Site 41HI101 was tested to determine the full nature of the deposits, but excavations determined that the site was not a significant archeological resource.

More recently, personnel from Prewitt and Associates, Inc., conducted two projects in the vicinity of Aquilla Lake. Scott (1998) surveyed a small, 3-acre area along the shore of the lake for the proposed location of a water supply pump station. No new sites were recorded. Arnn and Gadus (1999) conducted a survey for a 31-mile water pipeline from Aquilla Lake to Lake Pat Cleburne in northwestern Hill and southcentral Johnson counties. A total of seven new sites were recorded.

\section{OBJECTIVES AND METHODS OF INVESTIGATIONS}

Prefield preparations for the current project determined that 41 previously recorded archeological sites were within, or very near, the $6.5-\mathrm{ft}$ pool raise. A review of these sites was conducted using the Texas Historical Commission's Archeological Sites Atlas and literature from the previous archeological investigations conducted at Aquilla Lake. Since most of these sites were last assessed before the impoundment of the lake, it was considered necessary to revisit each of the 41 sites.

During prefield preparations, a discrepancy was noticed between site locations depicted on the Texas Archeological Sites Atlas and files provided by the U.S. Army Corps of Engineers. Several site locations indicated by the two sources did not match, and several sites overlapped in the same location. It was unclear which location was correct for some of the 41 sites, but once on the ground and after visiting several sites, it was determined that the site locations from the Archeological Sites Atlas were correct. In several cases, nothing existed where the U.S. Army Corps of Engineers mapping files had sites plotted. Therefore, site locations from the Archeological Sites Atlas were used for this project.

In addition to the previously recorded archeological sites, 10 areas within the $6.5-\mathrm{ft}$ pool raise zone were identified as unsurveyed or not adequately surveyed during previous investigations. These areas were identified by taking previous survey information from the Archeological Sites Atlas, overlaying it on a map of the lake depicting the proposed $6.5-\mathrm{ft}$ pool raise, and locating the areas that did not overlap. Most of these areas were near streams and low-lying areas around the lake and totaled 180 acres. Based on topographic maps alone, it could not be determined if these 10 survey areas had the potential to contain archeological deposits; therefore, it was necessary to visit and perform a reconnaissance survey in each of the areas, with shovel testing performed as needed. Areas identified for survey ranged from just less than 2 acres to 74 acres (Table 1). There were several other small portions of unsurveyed land around the lake, but in many cases they were less than a half acre and demonstrated a very low likelihood of containing archeological deposits. As a result, these areas were not surveyed.

During the field investigations, all revisited previously recorded and newly recorded archeological sites were photographed. Their

Table 1. Survey area acreage

\begin{tabular}{l|c}
\hline \multicolumn{1}{c|}{ Survey Area } & Acres \\
\hline SA-1 & 73.8 \\
\hline SA-2 & 49.1 \\
\hline SA-3 & 19.2 \\
\hline SA-4 & 11.0 \\
\hline SA-5 & 10.7 \\
\hline SA-6 & 6.1 \\
\hline SA-7 & 3.7 \\
\hline SA-8 & 3.2 \\
\hline SA-9 & 2.2 \\
\hline SA-10 & 1.3 \\
\hline
\end{tabular}


UTM coordinates were logged using a Trimble GeoXT handheld GPS unit, and current site conditions and landscape context were documented to assess their eligibility for listing in the National Register of Historic Places. Where surface evidence alone was insufficient for making an assessment, shovel tests were excavated to determine if subsurface cultural deposits were present and to assess the integrity of the site. Shovel tests were excavated in arbitrary $20-\mathrm{cm}$ levels to $100 \mathrm{~cm}$ below surface or until culturally sterile deposits were reached, whichever came first. The matrix from each shovel test was dry-screened through 1/4-inch-mesh hardware cloth. Shovel test forms were completed for each shovel test excavated, recording the presence or absence and quantity of cultural materials by level and the nature of the sediments. Only diagnostic artifacts were collected. These were labeled with appropriate provenience information and returned for temporary curation at the laboratory facilities at Prewitt and Associates, Inc., where they were washed, cataloged, and analyzed.

All of the field records were kept in a standard format. They included survey area maps and aerial photographs, the project archeologist's notes, shovel test record forms, photograph logs, and temporary site forms. All mapping information was collected on a GPS unit and transferred to a computer at the end of each workday.

\section{RESULTS OF THE SURVEY}

The archeological survey portion of the current investigations at Aquilla Lake resulted in the documentation of 3 new sites: 2 prehistoric lithic scatters and 1 historic well. Many of the 10 previously unsurveyed areas demonstrated a very low likelihood of containing buried deposits, or any type of archeological site, due to high rates of wave-action erosion around the lake. In addition, 41 previously recorded sites were revisited and reassessed. Eight of these sites (41HI107, 41HI108, 41HI109, 41HI110, 41HI150, 41HI151, 41HI152, and 41HI153) were consolidated into 3 sites (41HI107/108, $41 \mathrm{HI} 109 / 110$, and 41HI150-153) and are assessed as such below. The site descriptions below include what was known about the site before this project began, any cultural materials observed, and recommendations for eligibility in the National Register of Historic Places.

\section{Newly Recorded Sites}

\section{$41 H I 310$}

\section{DESCRIPTION}

Site $41 \mathrm{HI} 310$ is a small prehistoric lithic scatter on an eroded sandstone bench just north of an unnamed tributary of Aquilla Creek, 500 600 m northwest of the Old School boat ramp on the southwestern end of Aquilla Lake. The site measures $45 \mathrm{~m}$ (north to south) by $75 \mathrm{~m}$ (east to west). Vegetation in the area is dominated by post oaks. Recent disturbances come from constant cattle traffic and fluctuating lake levels. The surface is gravelly and deflated to bedrock in many areas. As a result, no shovel tests were excavated.

\section{CULTURAL MATERIALS OBSERVED}

Observed cultural materials include lithic debitage, a hammerstone, a core, and a possible ground stone tool fragment. A single piece of solarized glass was found, but no additional historic materials were encountered.

\section{ASSESSMENT}

The sparse number of artifacts and the lack of diagnostic tools make functional and chronological interpretations impossible. The site lacks buried and intact cultural deposits, hindering the ability of any future investigations to yield significant data to make these interpretations. Because of these factors, $41 \mathrm{HI} 310$ is recommended as ineligible for listing in the National Register of Historic Places.

\section{$41 H I 311$}

\section{DESCRIPTION}

Site $41 \mathrm{HI} 311$ is a prehistoric lithic scatter on an eroded sandstone point in the bend of an unnamed tributary of Aquilla Creek. It is 1.1-1.2 km south of the Old School boat ramp. The site is a small prehistoric lithic scatter measuring $60 \mathrm{~m}$ (north to south) by $50 \mathrm{~m}$ (east to west). Much of the area is covered with a dense stand of post oaks, with a few junipers scattered throughout, as well as greenbrier and other small saplings. The surface is covered in dense 
oak leaf litter with large sandstone bedrock slabs resting on the surface, demonstrating the deflated nature of the landform. Recent disturbances to the site include cattle traffic and fluctuating lake levels. Six shovel tests were excavated, two of which were positive. The average depth of the shovel tests was less than $10 \mathrm{~cm}$ before bedrock was encountered.

\section{CULTURAL MATERIALS OBSERVED}

Observed cultural materials include two flakes, two battered stones, and one tested cobble. All of these materials were recovered in a single shovel test. In another shovel test, a single quartz flake was recovered.

\section{ASSESSMENT}

Due to the sparse number of artifacts and absence of diagnostic materials, functional and chronological interpretations are very limited. Although the site did contain shallowly buried deposits, the deflated nature of the area makes it unlikely for any further investigations to yield additional data. Because of these factors, $41 \mathrm{HI} 311$ is recommended as ineligible for listing in the National Register of Historic Places.

\section{$41 H I 312$}

\section{DESCRIPTION}

Site $41 \mathrm{HI} 312$ is a historic well located on a terrace remnant along an unnamed drainage of Hackberry Creek, $500 \mathrm{~m}$ northeast of the FM 1947 bridge crossing on Aquilla Lake. This site is not located in one of the 10 survey areas but was recorded because it lies within the U.S. Army Corps of Engineers boundaries. The site is a hand-dug, stone-lined well; the entire site measures $25 \mathrm{~m}$ (north to south) by $25 \mathrm{~m}$ (east to west)(Figure 4). Around the well is a concrete box that probably supported a lid to keep debris from falling into the well. The well is ca. $5 \mathrm{ft}$. in diameter, with the box measuring ca. $7 x 7 \mathrm{ft}$. Several iron bolts with nuts protrude from the walls of the concrete box, and a single iron pipe with an elbow joint protrudes out of the ground just southeast of the box. A fence line runs along the tree line just east of the well; it appears that the area was originally fenced off to keep livestock out. It is not known if this well was part of a house or a larger farm complex. No shovel tests were excavated at this site because the historic materials were observed on the surface.

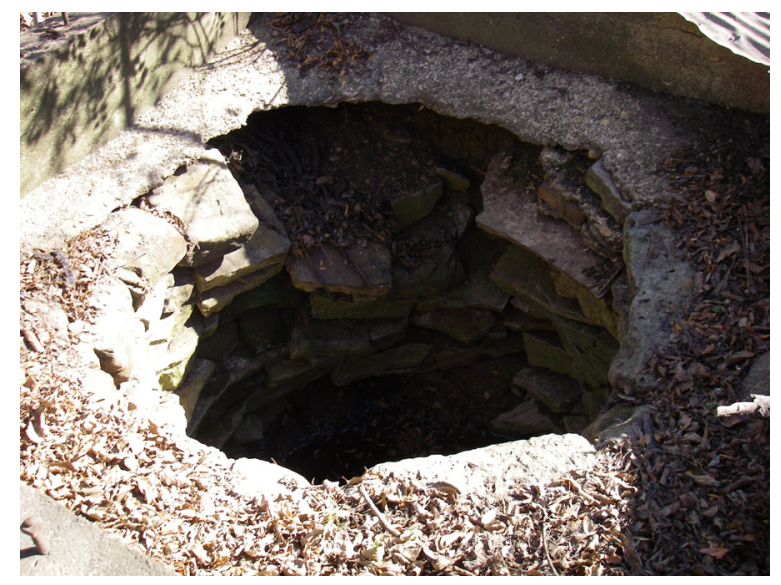

Figure 4. View of well opening at 41HI312.

\section{CULTURAL MATERIALS OBSERVED}

All of the cultural materials at this site were historic and observed on the surface. Materials observed include five 8-ft sheets of corrugated sheet metal, various sizes of machine-cut lumber, and net and barbed-wire fencing.

\section{SITE HISTORY}

Site 41HI312, a well, is on Tract AQ-254-2, which encompasses 312.16 acres out of four adjoining surveys, including a portion of the 1,280-acre Michael D. Castleman Survey southwestern quadrant in Hill County. The tract is situated along the east bank of Aquilla Lake and is northeast of FM 1947. The well was part of a former farmstead occupied from the last quarter of the nineteenth century through the mid-twentieth century.

Michael D. Castleman (ca. 1792-1855), a native of Davidson County, Tennessee, came to Texas in 1826 as part of Stephen F. Austin's colonizing efforts. As a single man, he received a first-class headright grant for one-third league of land he had located in Clay County on the west fork of the Trinity River (Texas General Land Office 1838, 1858; Williams 1996:81). In 1828, Castleman joined J. S. Sutton's company of mounted volunteers on the Nueces River near San Patricio at Camp Baranco (Texas Gen- 
eral Land Office 1858). He was a private in Sterling C. Robertson's Ranger Company in the Republic of Texas Army from July to October of 1836 , and completed another year of ranger service under the direction of Captain Thomas $H$. Barron, who discharged Castleman honorably on October 20, 1837, at Nashville-on-the-Brazos in present-day Milam County (Texas General Land Office 1848, 1854, 1858; Tyler 1936:28). Castleman was one of a few Fort Milam soldiers on a June 1837 excursion to cut a bee tree along the road to Perry Springs when Indians killed James Coryell (Simmons 1965:12; St. Romain 1951:27-28; Tyler 1936:41-42). He witnessed additional Indian turmoil when serving as a ranger with Bryant's Fighting Volunteers in January 1839, and as a private under Nimrod Doyle between March and June 1839 (Moore 2006:142, 184; Texas General Land Office 1858). Because of his military service, Castleman was awarded bounty warrant land grants of 320 and 1,280 acres. He lived in Robertson County in 1840. A portion of the county was reorganized as Limestone County in 1846, where he resided that year. He was still farming there 1850 when he held $\$ 9,000$ in real estate (Jackson 1999; U.S. Department of the Interior, Census Office 1850). He was a juror in Falls County in 1851 (The Lewis Publishing Company 1893:186). By 1854, he had retained the larger of his two bounty warrant land grant certificates and had the land located in Hill County along Aquilla Creek. The State of Texas patented the survey to Castleman on February 23, 1854 (Texas General Land Office 1848, 1854). After Castleman died in 1855, his heirs held title to the land. It is unlikely that any of the Castlemans ever occupied the property.

The first few years after the land on which site $41 \mathrm{HI} 312$ is situated was patented, it changed hands in quick succession. In December 1855 the heirs, represented by Andrew Castleman of Coryell County, sold 320 acres-the southwesterly quadrant out of the Castleman Survey-to brothers Jesse C. Blocker and William M. Blocker for $\$ 480$ (Hill County, Deed Records G:347, H:444). Just two weeks later, the brothers sold the land to LaMenton W. Cato (1809-1882) for $\$ 800$ (Anonymous 2011; Hill County, Deed Record H:634). In May 1856, LaMenton W. and Mary Catherine Rawls Cato sold the land to David Bridenthal for $\$ 1,000$ (Hill County, Deed Record H:635). It is unlikely that any of these owners occupied the land (Hill County, Ad Valorem Tax Records 1855, 1856).

It is unclear how long Bridenthal held the property. He paid taxes on 100 acres out of the Castleman Survey in 1859, which was then valued at $\$ 330$. He also owned three other parcels of land in Hill County, town lots in Hillsboro, eight slaves, seven equine, and 25 bovine (Hill County, Ad Valorem Tax Record 1859). In 1860, the Pennsylvania native was practicing law and living in Hillsboro with his Alabama-born wife and their five children, aged 2 months to 9 years, who were all born in Alabama. At the time, he held $\$ 2,000$ in real estate and had personal holdings of $\$ 16,000$ (U.S. Department of the Interior, Census Office 1860a). That year, he held seven slaves (U.S. Department of the Interior, Census Office 1860b). It is unlikely the Bridenthal family occupied the property, but slaves possibly worked on the land (Hill County, Ad Valorem Tax Record 1859).

It is unclear when or to whom Bridenthal conveyed his holdings out of the Castleman Survey, or who owned it for the next few decades (Hill County, Ad Valorem Tax Records 18601875; Hill County, Deed Records). However, by 1876, Mary Young Harvick (1836-1906) owned land out of the Castleman Survey, on which site 41HI312 is situated, and an adjacent parcel out of the Albert Pratt Survey (Bureau of Vital Statistics n.d.; Hill County, Ad Valorem Tax Record 1876). The Illinois-born woman was widowed in 1875, but had been in Hill County as early as 1860, when she and her husband Hampton J. Harvick (1832-1875), a native of Arkansas, were raising livestock with their family (Hood 2012; U.S. Department of the Interior, Census Office 1860a). They had two young children and his real estate holdings were limited to $\$ 200$ worth of unimproved land, but his personal estate was a chunky $\$ 2,634$. The family's livelihood derived from a 60-cow dairy that produced 400 pounds of butter (U.S. Department of the Interior, Census Office 1860a, 1860c). Harvick had served as a private in the Texas Cavalry, 30th Regiment, also known as Gurley's Regiment, First Partisans, during the Civil War (War Department Collection of Confederate Records n.d.). Between at least 1868 and 1873, the family was farming on land out of the Wesley Young Survey in Hill County (Hill County, Ad Valorem Tax Records 1868, 1871-1873; U.S. Department of the Interior, Census Office 1870a). In 1870, 
they had five Texas-born children and he owned 20 acres of improved, 20 acres of wooded, and 70 acres of pasture land valued at $\$ 1,500$ and held another $\$ 500$ in personal wealth. The farm was diversified and no longer based on the dairy business by this time (U.S. Department of the Interior, Census Office 1870a, 1870b). After her husband died, Mary Harvick continued to raise her family on her holdings out of the Castleman and Pratt Surveys, where she had a carriage, tools, equine, bovine, hogs, and miscellaneous property (Hill County, Ad Valorem Tax Records 1877-1883). In 1880, six of her children resided with her, and Nicholas Harvick, an older son, farmed nearby with his wife (U.S. Department of the Interior, Census Office 1880a). Her farm had 75 tilled and six woodland acres valued at $\$ 1,500$. The farm's crops and livestock holdings were a typical mix of subsistence and cash-crop production. The family consumed the milk and 25 pounds of butter two milch cows produced, meat from two swine, and 25 dozen eggs that three chickens laid. The Harvicks grew 15 acres of maize and 12 acres of broom corn for livestock feed and household use. Farm production yielded $\$ 135$, which included income from two bales of cotton grown on 14 acres (U.S. Department of the Interior, Census Office 1880b). By the mid 1880s, her son Romulus F. Harvick and his wife farmed nearby (Hill County, Ad Valorem Tax Record 1886). Throughout her ownership, the land out of the Pratt Survey consistently sustained its value at $\$ 10$ an acre, while her holdings out of the Castleman Survey gradually increased in worth from $\$ 3$ in 1877 , to almost $\$ 5$ in 1886 , to the $\$ 8$ range by the mid 1890 s. In 1900 , all of her land was appraised at $\$ 10$ an acre, and one year later it was valued at $\$ 12$ an acre. She gradually downsized her livestock holdings as her sons-Nicholas, Francis (Frank), and Cincinnati-ramped up their livestock holdings, although they held no land of their own (Hill County, Ad Valorem Tax Records 1877-1901). By 1900, Harvick was living on a farm with her youngest daughter's family (U.S. Department of the Interior, Census Office 1900).

In April 1901, the long-widowed Harvick sold 70 acres out of the Castleman Survey, on which site $41 \mathrm{HI} 312$ is situated, and an adjoining 20 acres out of the Pratt Survey to her youngest son, Cincinnati N. Harvick (1873-1954), for $\$ 1,935$ (Dorrycott and Dorrycott 2009; Hill County, Deed Record 62:491). He and his wife, Hennie Mae
Wakefield Harvick, farmed the property and had a few equine, bovine, and swine (Hill County, Ad Valorem Tax Records 1902-1904).

In November 1904, the Harvicks sold the land to James W. Vaughan for $\$ 2,520$ (Hill County, Deed Record 88:327). A native of Missouri, Vaughan was renting a farm in Hill County in 1900 (U.S. Department of the Interior, Census Office 1900). Vaughn also held two other similarly appraised parcels of land, and it is unclear which may have served as his homestead. His operation was fair sized, with up to 11 equine, 20 bovine, 40 swine, and three wagons or buggies (Hill County, Ad Valorem Tax Records 1905, 1906).

In November 1906, Vaughn sold 70 acres out of the Castleman Survey, on which site 41HI312 is situated, and an adjoining 20 acres out of the Pratt Survey to J. Benjamin Tarpley for $\$ 8,580$ (Hill County, Deed Record 98:377). The Tennessee native was farming with his Texas-born wife Dora and three children in Hill County by 1900 (U.S. Department of the Interior, Census Office 1900). Tarpley owned more than 400 acres in the county, and the family likely resided nearby on a more heavily improved parcel initially. By 1912, he had consolidated his holdings to two parcels totaling 162 acres out of the Castleman Survey and three parcels totaling 243 acres out of the Pratt Survey, all of which had risen in value to about $\$ 25$ an acre. However, it is unclear which of these parcels was the location of the family's homestead. The Tarpley's livestock holdings consisted of eight equine, five bovine, six swine, two wagons or buggies, and $\$ 120$ worth of tools in 1911 (Hill County, Ad Valorem Tax Records 1907-1911).

In September 1912, J. Benjamin and Dora Tarpley sold 70 acres out of the Castleman Survey, on which site $41 \mathrm{HI} 312$ is situated, and an adjoining 20 acres out of the Pratt Survey to Marion A. Forrest for $\$ 12,400$ (Hill County, Deed Record 137:59). The Missouri native and his Tennessee-born wife Callie were renting a farm in Hill County by 1900 (U.S. Department of the Interior, Census Office 1900). By 1910, they lived on a farm they owned with their six Texas-born children (U.S. Department of Commerce and Labor, Bureau of the Census 1910a). Forrest also owned a 156-acre parcel out of the Castleman Survey; both this and the 70-acre parcel were equally improved, and it is unclear which land the family occupied. He had a few 
equine, bovine, swine, two wagons or buggies, and $\$ 40$ worth of tools in 1912 (Hill County, Ad Valorem Tax Record 1912).

Between June 1913 and October 1916, ownership of the property changed several times and it is unclear whether the land was occupied. Marion A. and Callie Forrest sold land out of the Castleman and Pratt Surveys to William A. $\mathrm{McDonald}$ for $\$ 5,850$. This sale included three parcels out of the Castleman Survey of 15, 60, and 5 acres, that totaled 81.53 acres, and 10 adjoining acres out of the Pratt Survey (Hill County, Deed Record 143:584). McDonald had been renting a house on Magnolia Street in Hubbard with his wife Mary, and he was a barber in 1910 (U.S. Department of Commerce and Labor, Bureau of the Census 1910a). In January 1914, the McDonalds sold the land to Joseph M. Woodruff, of Ellis County, for $\$ 9,153$ (Hill County, Deed Record 149:538). In 1910, the Georgia native and his Mississippi-born wife Addie were renting a farm elsewhere in Hill County where they lived with her two small children (U.S. Department of Commerce and Labor, Bureau of the Census 1910a). In August 1914, Joseph M. and Addie Woodruff sold the land to Edgar C. Johnson, of Ellis County, for $\$ 9,153$ (Hill County, Deed Record 149:539). He and his wife Lizzie, both native Tennesseans, rented a farm along Wagonmaker Road in Ellis County with their daughter and a hired hand (U.S. Department of Commerce and Labor, Bureau of the Census 1910b). By 1920, he was a real estate agent in Ellis County, and the family no longer lived on a farm (U.S. Department of Commerce, Bureau of the Census 1920a). In August 1916, the Johnsons sold the land to George F. Beavers, W. H. Sanders, and Krum Kirkpatrick for $\$ 500$ (Hill County, Deed Record 151:553). Neither ownership nor appraised values for the land are reflected in local tax records between 1913 and 1916, and it is unclear whether the property was occupied (Hill County, Ad Valorem Tax Records 1913-1916).

In October 1916, Beavers, Sanders, and Kirkpatrick sold the 81.53 acres out of the Castleman Survey, on which site $41 \mathrm{HI} 312$ is situated, and the adjoining 10 acres out of the Pratt Survey to William B. and Martha (Mattie) E. Dandridge, for $\$ 9,153$ (Hill County, Deed Record 151:510). This price reflects the likelihood that the property retained many of its improvements. In 1910, the Dandridges, all natives of Mississippi, were farming, and five of their seven children lived at home. Two of their sons worked as farm laborers and a third was a general store bookkeeper (U.S. Department of Commerce and Labor, Bureau of the Census 1910a). By 1917, the Dandridges land out of the Castleman and Pratt Surveys was valued at about $\$ 30$ an acre and the land served as their homestead (Hill County, Ad Valorem Tax Records 1917-1920). In 1920, their two youngest sons, Lewis (Lee) L. and Charles P., lived with their parents and worked the family farm along Vaughan Road (U.S. Department of Commerce, Bureau of the Census 1920b). In November 1920, the Dandridges sold the land to their two youngest sons for $\$ 9,442$ (Hill County, Deed Record 194:502). It appears that the elder Dandridges continued to occupy the property until at least 1923, by which time their sons took responsibility for tax liabilities (Hill County, Ad Valorem Tax Records 1921-1922). By 1930, the Dandridges were renting a house on North Waco Street in Hillsboro. Lewis L. Dandridge, now working in retail sales, and an older son, William S., a farm laborer, lived with them. Charles P. and Minnie M. Dandridge lived in a house they owned on South Covington Street in Hillsboro and he worked as an automobile salesman (U.S. Department of Commerce, Bureau of the Census 1930). In 1930, the brothers defaulted on their loan and conveyed the land to the Union Central Life Insurance Company (Hill County, Deed Record 254:294).

In 1933, the Union Central Life Insurance Company sold the 81.53 acres out of the Castleman Survey, on which site 41HI312 is situated, and the adjoining 10 acres out of the Pratt Survey to Lafayette Franklin Shoemaker for $\$ 2,000$ (Hill County, Deed Record 266:1). Shoemaker had acquired several other land parcels in the vicinity between 1906 and 1923 (Hill County, Deed Records 96:406, 146:498, 147:543, 151:483, 172:57, 204:439). The Alabama-born Shoemaker (1868-1941) received a medical degree from the University of Alabama in 1902 and wed native Texan Florence Bell Johnson (1876-1956) the following year (Rootsweb 2012; University of Alabama 1903; U.S. Department of Commerce and Labor, Bureau of the Census 1910a). In 1906, they had a son, Harold S., who died in 1909 (Rootsweb 2012). They had a daughter in December 1909, were living on a farm they owned, and he also worked as a general physician (U.S. Department of Commerce and Labor, Bureau of the Census 1910a). An infant son died 
in 1911 (Texas Department of Health 1911). In 1920, the family was farming on Vaughan Road. They owned the property, but carried a mortgage (U.S. Department of Commerce, Bureau of the Census 1920b). By 1930, Shoemaker was practicing medicine in Hillsboro where the family rented a house at 322 East Elm Street for $\$ 30$ a month (U.S. Department of Commerce, Bureau of the Census 1930).

The Shoemakers remained in Hillsboro and likely rented their rural property to tenants. In 1938, a house, domestic outbuildings, and numerous agricultural outbuildings were extant (Figure 5). Land in pasture and row crops was in active use, as was terracing to help protect against erosion. Except along the bed of Aquilla Creek, no woodland remained on the property (Tobin International 1938). By 1952, the property had a few additional buildings and structures. Terracing was no longer evident, and woodlands along the creek bed had further thinned (U.S. Army Map Service 1952).

Florence Bell Johnson Shoemaker lived in Hillsboro when she died in 1956 (Whitener 2010). As their only surviving child and heir, Marian Elizabeth Shoemaker (1909-2006) inherited this land and her parents' other holdings after her mother's death (Hill County, Probate Minutes 75:421). She graduated from Baylor University and married Fred B. Horn in 1960. They resided in Hillsboro, where she was an avid pianist and music teacher and devoted to the First Baptist Church (Shelley 2006). It is unclear when the holdings out of the Castleman and Pratt Surveys were no longer occupied, but no resources were extant by 1975 (U.S. Geological Survey 1975).

Marian Shoemaker Horn and her husband conveyed the 81.53 acres out of the Castleman Survey, on which site $41 \mathrm{HI} 312$ is situated, and the adjoining 10 acres out of the Pratt Survey to the U.S. Army Corps of Engineers on March 20,1978 , for $\$ 167,235$. This transaction included an additional 220.63 acres out of the Castleman and Pratt Surveys and the adjoining John S. Hobley and Miguel Zunigas Surveys. Combined, these parcels became Tract AQ-254-2 under the supervision of the U.S. Army Corps of Engineers. The transaction also included two additional land parcels (Tracts AQ-254-1 and AQ-254-3) totaling 22.31 acres out of the Robert Morris Survey (Hill County, Deed Record 569:155). Many of the associated resources were situated on an adjacent Tract AQ-300, which the U.S. Army Corps of Engineers also purchased out of the Pratt Survey.

In summary, although the 81.53 acres out of the Castleman Survey may have been occupied earlier, the first known occupant was the widowed Mary Harvick. With her children, she farmed the land on which the well (site 41HS312) is situated between 1876 and 1901. It is very likely that the Harvick family dug the well and used it as a water source. Harvick's youngest son, Cincinnati N. Harvick, and his family resided on and farmed the property between 1901 and 1904. Possible owner occupants in subsequent years were James W. Vaughan (1904-1906), J. Benjamin and Dora Tarpley (1906-1912), and Marion A. and Callie Forrest (1912-1913). It is unlikely that the property was owner-occupied between 1913 and 1916, but tenants may have farmed the land. From 1916 until at least 1923, William B. and Martha E. Dandridge owned and resided on the land. Two of their sons may have farmed the property until 1930. They likely did not reside on the land, but it could have been tenant occupied. It is unclear whether the property was occupied between 1930 and 1933. Lafayette Franklin and Florence Bell Johnson Shoemaker owned the land from 1933 until their deaths, but likely did not occupy the property. Their heir, Marian Shoemaker Horn, did not occupy the land. Thus, after 1933, tenants most likely occupied and used the several domestic and agricultural buildings and structures that remained extant on the farm through at least 1952; however, it is unclear what role the well played in the twentieth-century use of the farm.

\section{ASSESSMENT}

Although the proposed lake level raise will completely submerge the well, the site has very limited archeological potential. It is therefore recommended that $41 \mathrm{HI} 312$ is ineligible for listing in the National Register of Historic Places.

\section{Previously Recorded Sites}

\section{HI74/114}

\section{DESCRIPTION}

Site $41 \mathrm{HI} 74 / 114$ is a prehistoric campsite and historic artifact scatter along a ridge and 


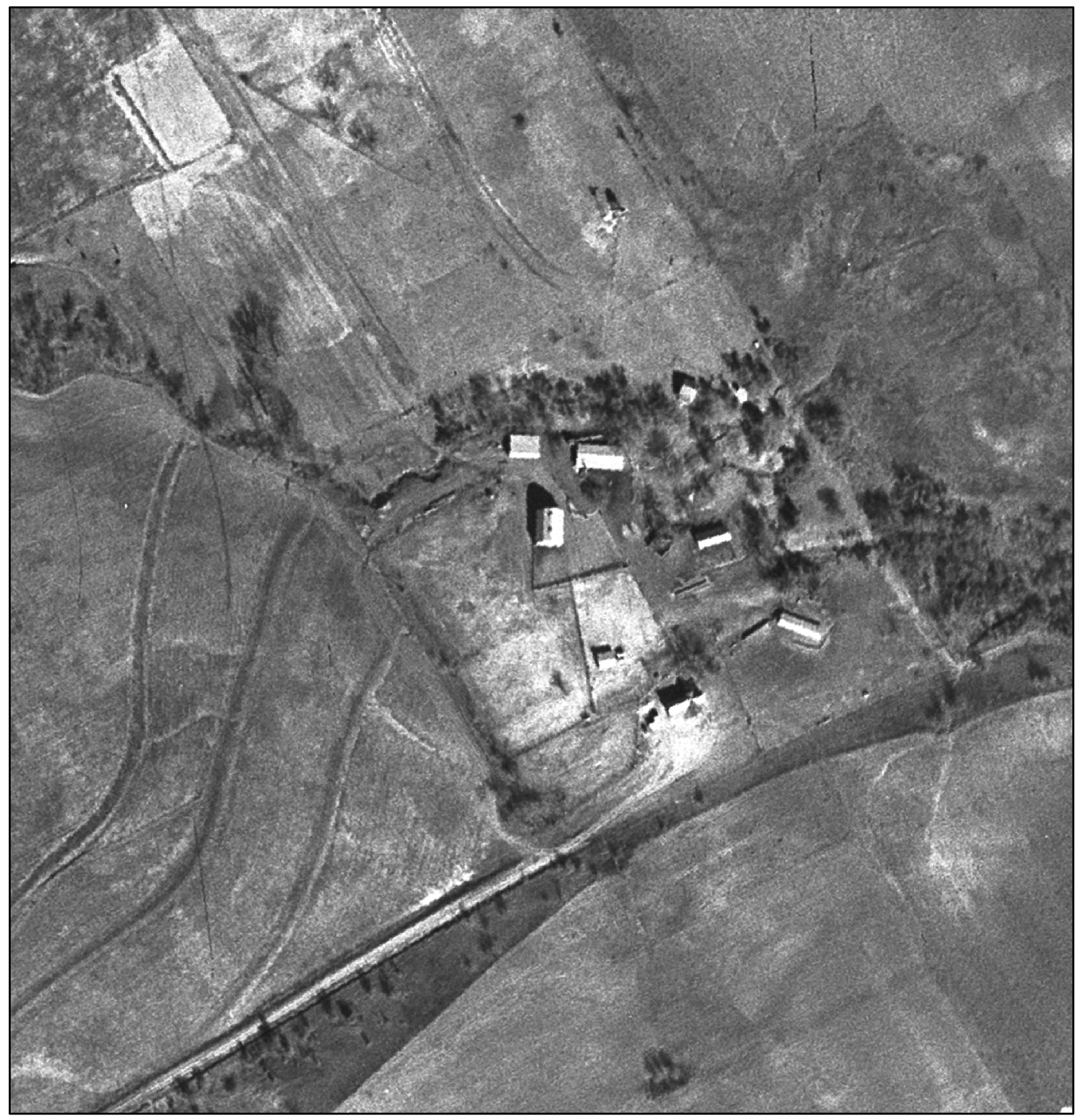

Figure 5. In 1938 the farm had a house, related domestic outbuildings, several large agricultural outbuildings, clearly indicated fence lines for livestock operations, and terraced row crops (Tobin International 1938).

terrace just above and west of Aquilla Creek. The site sits $380 \mathrm{~m}$ southeast of the center of the FM 1534 bridge crossing the upper end of the reservoir. Frank Bryan (1931) collected artifacts from this site in the 1930s. Later investigations by SMU assigned two numbers to this site (x41HI98 in Skinner and Henderson 1972 and $x 41 H I 170$ in Skinner et al. 1978). Subsequently, Brown (1987:30-1 to 30-23) des- ignated the site as $41 \mathrm{HI} 114$, though later it was discovered that it had previously been recorded as $41 \mathrm{HI} 74$. Both designations have been kept. The later work conducted by Brown (1987) consisted of forty-three 4-m-diameter surface collection units and three $1 \times 2-m$ excavation units. Only 23 of the surface collection units yielded artifacts, whereas the excavation units yielded 3 projectile points, 6 bifaces, 12 modified 
flakes, 7 cores, 1,129 pieces of unmodified debitage, and 1 burned rock feature. The overall depths of these units ranged from 70 to $85 \mathrm{~cm}$ below surface. Diagnostic artifacts recovered from the site included 2 Gary, 1 Godley, and 1 Yarbrough dart point. Although the materials and feature recovered from these investigations represented a variety of activities, Brown (1987:30s-23) noted evidence of disturbance and thought the contextual integrity of the materials was poor. Brown (1987:30-23) concluded that the site had limited interpretive value.

Currently, much of the site is underwater, but a significant portion with buried deposits and intact sediments remains above water, forming a narrow peninsula that juts out into the reservoir (Figure 6). What remains above water measures $300 \mathrm{~m}$ (north to south) by $70 \mathrm{~m}$ (east to west) with slight variations due to the fluctuating shoreline. Vegetation on the landform consists of willow, black locust, and bois d'arc trees with various grasses, greenbrier, and poison ivy. A total of 10 shovel tests were excavated, with all 10 recovering cultural materials. Depths of the shovel tests ranged from 30 to $100 \mathrm{~cm}$ below surface, with an average depth of $55 \mathrm{~cm}$.

\section{CULTURAL MATERIALS OBSERVED}

Shovel tests yielded both prehistoric and historic cultural materials. Prehistoric materials consist of 2 dart point fragments (1 Godley base), 2 biface fragments, 1 scraper, possible ground stone tool fragments and burned rocks, and 120 flakes. Historic materials include bottle glass fragments, window glass, whiteware, stoneware, cut and wire nails, and bricks. Only the Godley point fragment was collected.

\section{ASSESSMENT}

Based on previous work done at this site, and the recent recovery of a Godley point fragment and historic materials, the site was occupied during the Late Archaic and Historic periods. Buried cultural materials are ubiquitous across the site. While erosion is impacting areas along the shoreline, deposits from which the artifacts were recovered are intact. These factors demonstrate the potential for the site to yield significant archeological data. Site 41HI74/114 is therefore recommended as potentially eligible for listing in the National Register of Historic
Places. Additional subsurface testing should be performed to determine the full extent and nature of the deposits.

\section{Brazil Site, $41 \mathrm{HI75}$}

\section{DESCRIPTION}

Site $41 \mathrm{HI} 75$ is a prehistoric campsite and historic house site situated on an eroding ridge, terrace remnant, and floodplain just above and west of Aquilla Creek. The site was first reported in the 1930s by Frank Bryan (1937:72-75) and Frank Watt (1938:Figure 2). Skinner and Henderson (1972) recorded it as two separate sites based on differences in landform morphology: $\mathrm{x} 41 \mathrm{HI} 66$ on the ridge and terrace remnant and $\mathrm{x} 41 \mathrm{HI} 72$ on the floodplain. In 1975, the floodplain portion of the site was tested by means of shovel tests and eight 1x1-m test units (Lynott and Peter 1977:60-63). These subsurface investigations yielded cultural materials to at least $40 \mathrm{~cm}$ below the ground surface. A limited amount of testing was conducted on the upper portion of the site in the form of six shovel tests and two 1x1-m test units in 1977 (Skinner et al. 1978). Artifacts were recovered from a depth of up to $1.1 \mathrm{~m}$. Diagnostic artifacts from the Early Archaic, Late Archaic, and Historic periods were recovered.

A subsequent season of testing was conducted in 1978 by SMU with an emphasis on isolating discrete temporal components; this work was reported in Brown (1987:31-1 to 31-44). Seven backhoe trenches, 13 test units, and an indeterminate number of shovel tests were excavated primarily on the floodplain portion of the site. The excavations yielded 19 projectile points, 32 bifaces, 118 pieces of modified debitage, 31 cores, 3,829 pieces of unmodified debitage, and 5 hammerstones. The site also included portions of two historic farmsteads, with two small structures and their associated artifacts and debris on the upland and downslope portions of the site. Diagnostic artifacts indicate that the site was occupied during the Paleoindian, Early and Late Archaic, Late Prehistoric, and the late nineteenth and early twentieth centuries. Brown (1987:31-44) noted that the prehistoric assemblage from the site reflected a limited but consistent range of activities through time. Since the site lacked features, midden areas, and diversified tool kits, 


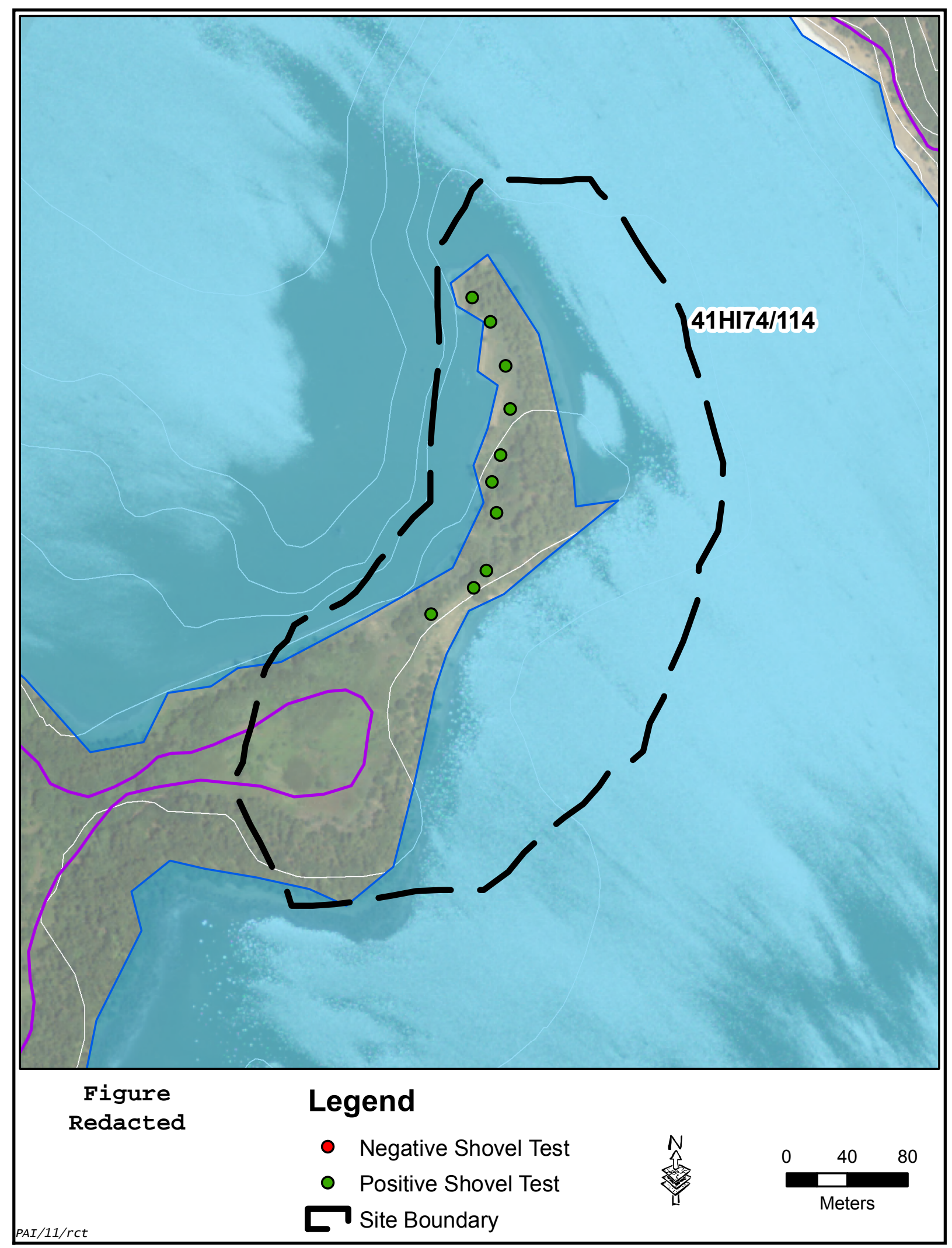

Figure 6. Map of 41HI74/114. 
Brown suggested that it was intermittently used as a short-term hunting camp. He noted that both the upland and floodplain portions of the site lacked contextual integrity since artifacts of varying ages were recovered from mixed contexts.

A majority of the site was submerged when Aquilla Lake was created. However, a small segment of the site remains above water as a small island in the lake. This island site is ca. $1.6 \mathrm{~km}$ northeast of the Old School boat ramp. The portion of the site above water measures $50 \mathrm{~m}$ (north to south) by $150 \mathrm{~m}$ (east to west). Although the island is small, much of the original vegetation still thrives there. Trees include willows, post oaks, and other small saplings; tall bunch grass grows mostly along the shoreline. Poison ivy and greenbrier are also abundant. Sediments are relatively thin on the landform. Six shovel tests were excavated, five of which terminated at $20 \mathrm{~cm}$ below surface. Those five shovel tests recovered cultural materials.

\section{CULTURAL MATERIALS OBSERVED}

A total of 21 flakes were recovered from shovel tests. Additional flakes, as well as 2 hammerstones and scattered burned rocks, were also seen on the surface of the site near the shoreline. A possible hearth feature was recorded. The hearth consists of a cluster of burned rocks eroding out of the surface of the site. Historic material recovered includes fragments of bottle glass, stoneware, and a butter churn lid.

\section{ASSESSMENT}

Although sediment on this landform is thin, buried archeological deposits remain. Numerous projectile point types from the Paleoindian through Late Prehistoric periods have been recovered at this site. In 1975, the floodplain portion of the site was minimally tested because the landowner would not allow access to the terrace slope (Brown 1987:31-2). In 1977, limited access was allowed on the terrace portion, and intact deposits were encountered to a depth of up to $1.1 \mathrm{~m}$ (Brown 1987:31-2). All that remains of the site currently are the highest portions. Based on current conditions and those reported by Brown, subsurface testing would likely yield little to no additional information about this site. Based on these factors, $41 \mathrm{HI} 75$ is recommended as ineligible for listing in the National Register of Historic Places.

\section{Bailey Site, $41 \mathrm{HI77}$}

\section{DESCRIPTION}

Site $41 \mathrm{HI} 77$ is an open campsite on an upland slope on the west side of Aquilla Creek, $1.12 \mathrm{~km}$ east of the Old School boat ramp. Bryan (1937:72) collected artifacts from the site in the 1930s, and Skinner and Henderson recorded the site as x41HI199 (1972:27). In 1975 Lynott and Peter (1977:96-100) excavated eight shovel tests and eight $1 \mathrm{x} 1-\mathrm{m}$ test units. Additional test excavations, consisting of sixteen $1 \times 1-m$ units and 18 or 19 shovel tests, took place in 1977 (Skinner et al. 1978:70-76). The recovery of diagnostic artifacts demonstrated repeated use of the site from the Early Archaic through the Late Prehistoric periods. More excavations conducted in 1980 consisted of two 2x2-m units (Brown 1987:26-3). The excavations reached a maximum depth of $50 \mathrm{~cm}$ below surface and yielded 2 burned rock features, 34 projectile points, 20 bifaces, 1 uniface, 113 modified flakes, 22 cores, 6,333 pieces of unmodified debitage, and 4 ground and battered stone tools. Brown (1987:26-31) noted that the distribution of the projectile points "illustrates the degree to which the archeological materials have been mixed." This, along with the relatively shallow and thin nature of the cultural deposits, led Brown to conclude that the site had limited interpretative value.

Currently, most of the site is submerged, but a small portion remains above the water level on the western shore of the reservoir. Not enough of the site remains to get an accurate measurement of the overall site size. What does remain has been severely disturbed by wave action from the lake. The ground surface is eroded down to clayey subsoil in most areas, leaving few artifacts in good context. Because of the almost complete lack of a soil mantle, no shovel tests were excavated.

\section{CULTURAL MATERIALS OBSERVED}

Observed cultural materials include lithic debitage, cores, and hammerstones. 


\section{ASSESSMENT}

Although various prehistoric artifacts were observed at this site, erosion has left them on a deflated surface and out of context. The site lacks buried and intact cultural deposits, hindering the ability of any future investigations to yield significant data. Because of these factors, $41 \mathrm{HI} 77$ is recommended as ineligible for listing in the National Register of Historic Places.

\section{HI107/108}

\section{DESCRIPTION}

Sites $41 \mathrm{HI} 107 / 108$ is a lithic scatter along a terrace remnant just southwest of Hackberry Creek. The site is $700 \mathrm{~m}$ northeast of the FM 1947 bridge crossing on the east side of the lake. It was originally recorded as two sites$\mathrm{x} 41 \mathrm{HI} 120$ and $\mathrm{x} 41 \mathrm{HI} 121$-by Skinner and Henderson (1972:29-30). They collected several artifacts from the surface, including a Scallorn arrow point. In 1983, when revisiting the sites, archeologists from the Texas Archeological Survey failed to relocate 41HI108, and there was confusion about the actual location of both of these sites (Brown 1987). According to site forms, they were within $60-70 \mathrm{~m}$ of each other. Because the sites were in such close proximity, it is likely that they are actually the same site. To avoid further confusion, Brown (1987) combined them into one site, 41HI107/108. The additional work at the site conducted by Brown (1987:13-1 to 13-5) consisted of surface collecting. This work recovered far fewer artifacts than that of Skinner and Henderson: three pieces of unmodified debitage and one mussel shell fragment. The low artifact density suggested to Brown (1987:13-4) that the materials were probably in a secondary context, removed and transported downslope by erosion.

During the current investigations, it was noted that much of the area is disturbed. A large east-to-west trending gully has cut into the surface, and a cleared road path extends down to the current shoreline. Vegetation consists of a mix of hardwood regrowth, greenbriers, and dense, short grasses. Eight shovel tests averaging $30 \mathrm{~cm}$ deep were excavated throughout the site, with only one yielding cultural materials.

\section{CULTURAL MATERIALS OBSERVED}

The only cultural materials recovered from this site were two flakes from one shovel test.

\section{ASSESSMENT}

It is possible that the location of $41 \mathrm{HI} 107 / 108$ was not plotted correctly when it was originally recorded. With the site only measuring $40 \times 50 \mathrm{~m}$, it is a small, sparse lithic scatter. Although there is an accumulation of sediment at the site, buried cultural materials are too sparse to warrant additional subsurface testing. Site $41 \mathrm{HI} 107 / 108$ is therefore recommended as ineligible for listing in the National Register of Historic Places.

\section{HI109/110}

\section{DESCRIPTION}

Site 41HI109/110 is a lithic scatter and lithic resource procurement area along the upland slope, terrace, and floodplain west of Hackberry Creek. It was originally recorded as five separate sites-x41HI81, x41HI82, x41HI83, x41HI84, and $\mathrm{x} 41 \mathrm{HI} 85$-by Skinner and Henderson (1972:24-25). Surface-collected artifacts from these sites included Paleoindian, Late Archaic, and Late Prehistoric projectile points and a single bone-tempered pottery sherd. Lynott and Peter (1977:70-76) later performed limited test excavations at $\mathrm{x} 41 \mathrm{HI} 81$ and $\mathrm{x} 41 \mathrm{HI} 82$. No artifacts were recovered from $\mathrm{x} 41 \mathrm{HI} 81$, but they analyzed 292 artifacts collected by Skinner and Henderson (1972). The work at $\mathrm{x} 41 \mathrm{HI} 82$ yielded 284 artifacts, and they analyzed another 28 artifacts collected by Skinner and Henderson. The artifacts from both sites primarily consisted of unmodified debitage, as well as small numbers of flake tools, bifaces, cores, and untypeable projectile point fragments. Lynott and Peter (1977) concluded that both sites were deflated and disturbed.

Test excavations and surface collections conducted by Lynott and Peter (1977:76-90) at $\mathrm{x} 41 \mathrm{HI} 83, \mathrm{x} 41 \mathrm{HI} 84$, and $\mathrm{x} 41 \mathrm{HI} 85$ also revealed that these sites were shallow and deflated. These investigations yielded varying amounts of artifacts, with $\mathrm{x} 41 \mathrm{HI} 83$ yielding the most $(\mathrm{n}=1,052)$ and $\mathrm{x} 41 \mathrm{HI} 84$ producing the least $(\mathrm{n}=170)$. The artifacts from all three sites consisted primarily of unmodified debitage, though 
x41HI83 and x41HI85 also produced 106 and 65 cores respectively, as well as projectile points, bifaces, and flake tools. Site x41HI84 yielded only seven tools. Projectile points consisted of Paleoindian, Early and Late Archaic, and Late Prehistoric types.

Starting in 1980, field investigations and site assessments by Brown (1987:23-5) found that $\mathrm{x} 41 \mathrm{HI} 81$ and $\mathrm{x} 41 \mathrm{HI} 82$ were linked by a light scatter of artifacts. The two sites were combined and designated 41HI109. A consistent scatter of artifacts also was observed between $\mathrm{x} 41 \mathrm{HI} 83$, x41HI84, and x41HI85 (Brown 1987:24-5). These three sites were combined and designated 41HI110.

In 1980 and 1982, Brown (1987) conducted controlled surface collections and excavated two backhoe trenches, two shovel tests, and one $2 \times 2-m$ test unit at $41 \mathrm{HI} 109$. In total, 6 projectile points, 16 bifaces, 3 unifaces, 5 pieces of edge-modified debitage, 3 , cores, 455 pieces of unmodified debitage, and 2 ground stone tools were recovered (Brown 1987:2312). The projectile points included Forney and Godley types. Based the artifact assemblage, the projectile point types, and the ceramic sherd collected by Skinner and Henderson (1972), Brown (1987:23-28) suggested that the site had witnessed limited occupations and activities, including lithic reduction, during the Late Archaic and Late Prehistoric periods. Brown (1987) also noted that the context of the artifacts was primarily surficial and that the few subsurface artifacts were probably from disturbed contexts.

Also in 1980 and 1982, Brown (1987) conducted surface collections and subsurface excavations in the form of two shovel tests and two $2 \times 2-m$ test units at 41 HI110. These investigations yielded 15 projectile points, 51 bifaces, 6 unifaces, 12 pieces of edge-modified debitage, 25 cores, 1,918 pieces of unmodified debitage, and 19 ground stone tools (Brown 1987:24-18). The projectile points included a Bonham-like arrow point and Angostura, Bulverde-like, Darl-like, Ellis, Gary, Godley, and Pedernales dart points. The artifact assemblage and diagnostic materials indicate that the site was repeatedly occupied from the late Paleoindian through Late Prehistoric periods, and that these occupations were primarily centered around the early stages of lithic reduction (Brown 1987:24-48). While a substantial amount of cultural materials were recovered from subsurface contexts, Brown (1987:24-48) noted that "there was little evidence to suggest that any of this material was in situ." Brown also noted there was even less evidence that any of the materials could be assigned to a particular component.

The current investigations noted that both $41 \mathrm{HI} 109$ and 41HI110 are on the same landform in close proximity to one another, and artifacts from each site tend to date to the same time periods, so for management purposes they have been combined into one site. The combined site is $1 \mathrm{~km}$ southwest of the Dairy Hill boat ramp near a water intake facility. Currently, most of the site is underwater, and many of the artifacts observed have been washed in by wave action from the submerged portion of the site (Figure 7). Numerous flakes can be seen in the sorted beach gravels that are deposited along the shore (Figure 8). Inland from the shoreline, erosion has washed away much of the overlying sediment, exposing the roots of many trees, clayey subsoil, and sandstone bedrock. Vegetation across the site consists of scattered elm and oak trees, with small saplings growing in between. The site measures $500 \mathrm{~m}$ (north to south) by $50 \mathrm{~m}$ (east to west), forming a crescent shape that follows the ridge. Two shovel tests were excavated on the north end of the site where sediments appeared to be intact. Only one yielded cultural materials, but neither shovel test could be excavated below $15 \mathrm{~cm}$.

\section{CULTURAL MATERIALS OBSERVED}

Observed cultural materials include lithic debitage and one core. All of the debitage, except for one flake, were found among the beach gravels that have washed ashore.

\section{ASSESSMENT}

Overall, few of the cultural deposits remain intact or in context at 41HI109/110. Erosion has completely removed the overlying soil mantle in the area. The site lacks buried and intact cultural deposits, hindering the ability of any future investigations to yield significant data on age and function of the site. Because of these factors, 41HI109/110 is recommended as ineligible for listing in the National Register of Historic Places. 


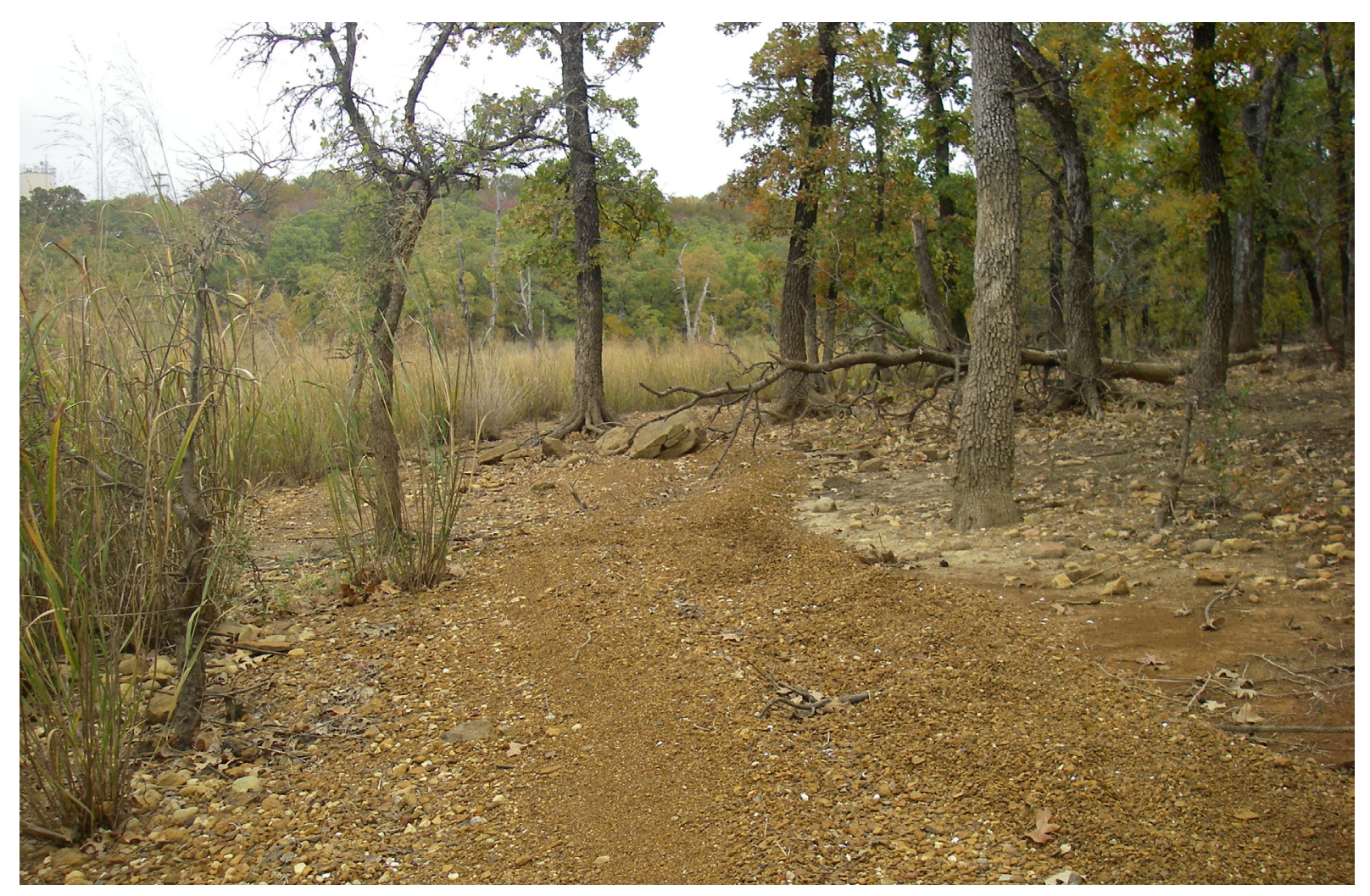

Figure 7. View of beach gravels deposited by wave action within 41HI109/110.

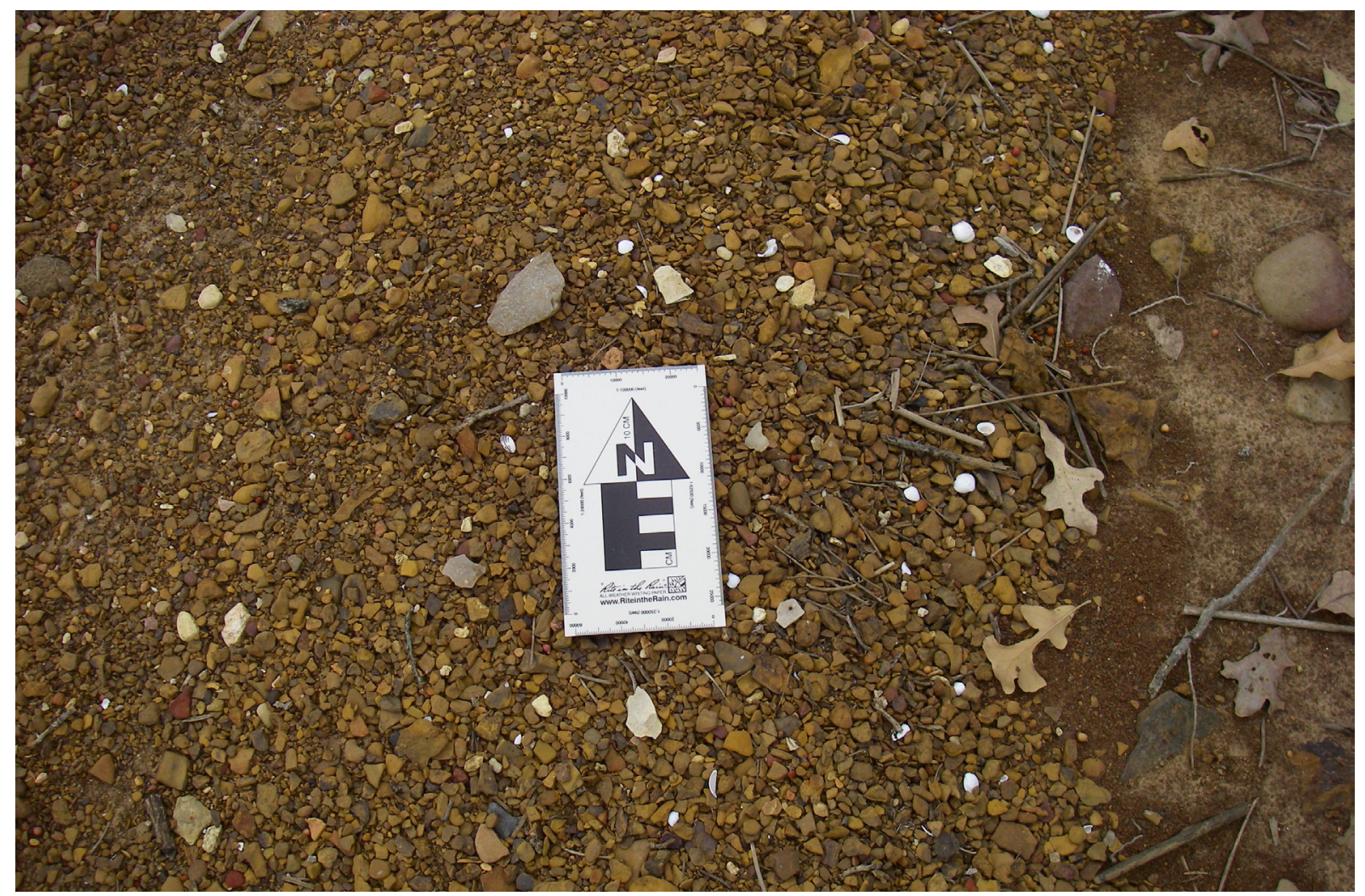

Figure 8. View of lithic debitage among beach gravels within 41HI109/110. 


\section{$41 H I 111$}

\section{DESCRIPTION}

Site $41 \mathrm{HI} 111$ is a lithic scatter on an upland ridge east of Hackberry Creek ca. $1.4 \mathrm{~km}$ southwest of the Dairy Hill boat ramp. Skinner and Henderson originally recorded it as x41HI86 (Skinner and Henderson 1972:28). Shovel testing conducted by Lynott and Peter (1977) revealed that the soil mantle at this site is extremely shallow. Because the site was so disturbed, a surface collection was made. Much of the assemblage consisted of lithic material, but the low number of artifacts and limited variety of tools suggested that the site served as a foraging station (Lynott and Peter 1977:93). In 1982, Brown returned to $41 \mathrm{HI} 111$ with the Texas Archeological Survey to conduct limited testing. Fourteen shovel tests were excavated, yielding no artifacts. In addition, a single 1x2-m unit was excavated. Ultimately, Brown concluded that the assemblage from the site was too small to attempt to label it with definitive site type.

Currently, most of the site is underwater. According to site maps, only a small portion of the site measuring ca. $80 \times 40 \mathrm{~m}$ remains above water. Vegetation consists of post oak trees with tall grasses along the shoreline. The surface is generally deflated and rocky, with some areas of sediment accumulation remaining upslope. A single shovel test was excavated in one of the few areas with sediment to a depth of $40 \mathrm{~cm}$; it yielded two flakes.

\section{CULTURAL MATERIALS OBSERVED}

Cultural materials observed include more than 50 flakes, several tested cobbles, and a biface fragment. With the exception of two flakes, all of the cultural materials observed were found on the surface. The majority of the flakes were found in the beach gravels along the shoreline and were probably washed in from the submerged portions of the site.

\section{ASSESSMENT}

Most of the site has succumbed to erosion, with little remaining intact or undisturbed. Although artifact densities are somewhat high, there is little or no soil mantle left containing intact buried deposits; therefore, very little could be learned from further archeological work. Site 41HI111 is therefore recommended as ineligible for listing in the National Register of Historic Places.

\section{$41 H I 128$}

\section{DESCRIPTION}

Site $41 \mathrm{HI} 128$ is a Late Archaic open campsite situated along a north-south trending ridge just east of the Aquilla Creek floodplain (Figure 9 ). It was originally recorded as $\mathrm{x} 41 \mathrm{HI} 112$ by Skinner and Henderson (1972:28). Currently, the entire site is above water and will remain so after the reservoir pool is raised. The site is relatively large, measuring $230 \mathrm{~m}$ (north to south) by $100 \mathrm{~m}$ (east to west). Vegetation consists of clusters of elm, oak, and juniper trees, with a few black locust and mesquite trees. A majority of the site, however, is open pasture, with various grasses completely covering the ground surface. It is possible that this area was once cultivated on a regular basis, though the soil mantle remains intact. Twenty shovel tests were excavated across the site, 15 of which were positive. Currently, the area is used to run cattle, and County Road 2415 runs just along the north edge of the site.

\section{CULTURAL MATERIALS OBSERVED}

A total of 60 flakes and one hammerstone were recovered from the shovel tests. Cultural materials were recovered from every level, with some areas of the site being deeper than others. Certain areas of the site contained a very thin soil mantle, with shovel tests reaching a depth of only $10 \mathrm{~cm}$. In other areas, shovel tests ranged between 70 and $90 \mathrm{~cm}$ deep. The average depth of the shovel tests across the site was $43.5 \mathrm{~cm}$.

\section{ASSESSMENT}

Despite the lack of recovery of diagnostic artifacts, 41HI128 produced substantial lithic debitage. All materials recovered were from buried contexts, and, based on the recovery, the site appears to be well stratified. Because this site contains intact buried deposits with possibly discrete components and stratification, 41HI128 is recommended as potentially eligible for listing in the National Register of Historic Places. However, since the proposed pool raise will not 


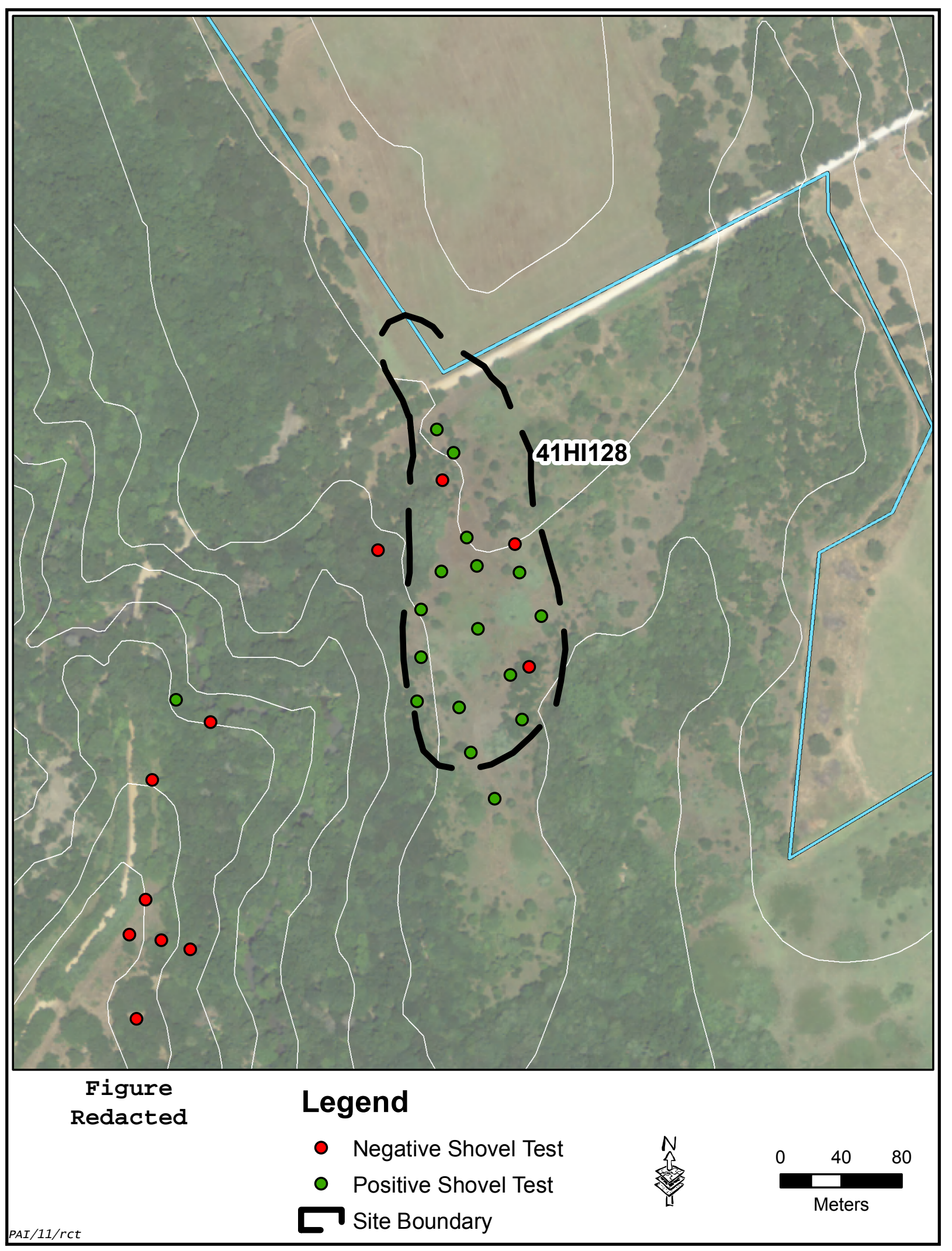

Figure 9. Map of 41HI128. 
impact the site, additional subsurface testing is not recommended unless future undertakings adversely impact $41 \mathrm{HI} 128$.

\section{$41 H I 131$}

\section{DESCRIPTION}

Site $41 \mathrm{HI} 131$ is a lithic resource procurement area along a ridge slope on the east side of Aquilla Creek ca. $350 \mathrm{~m}$ north/northwest of the FM 1534 bridge crossing on the east side of the channel. It was originally recorded as two sites-x41HI101 and x41HI104-by Skinner and Henderson (1972:27). The two sites were later combined and designated $41 \mathrm{HI} 131$ by Brown (1987). A 20-m-wide power line right of way bisects the site from east to west. Overall, the site measures ca. $250 \mathrm{~m}$ (north to south) by $50 \mathrm{~m}$ (east to west). In areas of the site that have not been cleared, vegetation consists of post oak trees, tall grasses, and greenbrier. Many gravels and cobbles litter the surface of the landform, with the highest concentrations in the disturbed power line right of way. Due to the site's presence on a natural outcropping of gravels, no shovel tests were excavated.

\section{CULTURAL MATERIALS OBSERVED}

Several tested cobbles, hammerstones, and flakes were observed, as well as one core.

\section{ASSESSMENT}

Despite the presence of artifacts indicating that $41 \mathrm{HI} 131$ is a lithic procurement site, the low density of artifacts and their surficial context suggest it is unlikely that further investigations would yield significant information. Therefore, $41 \mathrm{HI} 131$ is recommended as ineligible for listing in the National Register of Historic Places.

\section{$41 H I 134$}

\section{DESCRIPTION}

Site $41 \mathrm{HI} 134$ is a Late Prehistoric open campsite on the banks of a meander loop of Hackberry Creek, $1.3 \mathrm{~km}$ north-northwest of the intersection of County Roads 2452 and 2453 (Figure 10). Vegetation around the site is a mix of elm and hackberry trees, with tall grasses.
The actual size of the site is unknown. The site was originally recorded as $\mathrm{x} 41 \mathrm{HI} 44$ by Skinner and Henderson (1972:33). Previous investigations yielded a single Caddo pottery sherd and lithic materials exposed in the cutbank along the stream. This suggests that the site is deeply buried, 1.0-1.5 m below surface.

\section{CULTURAL MATERIALS OBSERVED}

No cultural materials were observed on the surface or in any of the cutbank exposures along the stream.

\section{ASSESSMENT}

Based on the likelihood of the site containing buried cultural deposits, mechanical trenching along with hand excavations should be conducted. Site 41HI134 is recommended as potentially eligible for listing in the National Register of Historic Places.

\section{$41 H I 135$}

\section{DESCRIPTION}

Site $41 \mathrm{HI} 135$ is an open campsite, lithic scatter, and historic artifact scatter on a ridge on the north side of a east-west trending tributary of Aquilla Creek, $600 \mathrm{~m}$ north/northeast of the Old School boat ramp. It was originally recorded by the Texas Archeological Survey in 1982. Most of the site is now submerged, but a portion remains on a small ridge just above the reservoir level. Vegetation in this area consists of mainly post oak trees and short grasses with a few juniper and mesquite trees. Due to fluctuating lake levels and wave action, much of the site along the shoreline has been completely eroded to the clayey subsoil and bedrock, and many large sandstone slabs are exposed on the surface. In topographically higher areas of the site, erosion has washed away much of the sediment or soil mantle as well. Because of this, shovel tests were not excavated.

\section{CULTURAL MATERIALS OBSERVED}

All artifacts recovered at the site were found on the surface. Cultural materials include 5-10 fragments of burned rock, 5 flakes, and various historic artifacts. Historic artifacts include several bricks, glass bottle fragments, 2 Rock- 


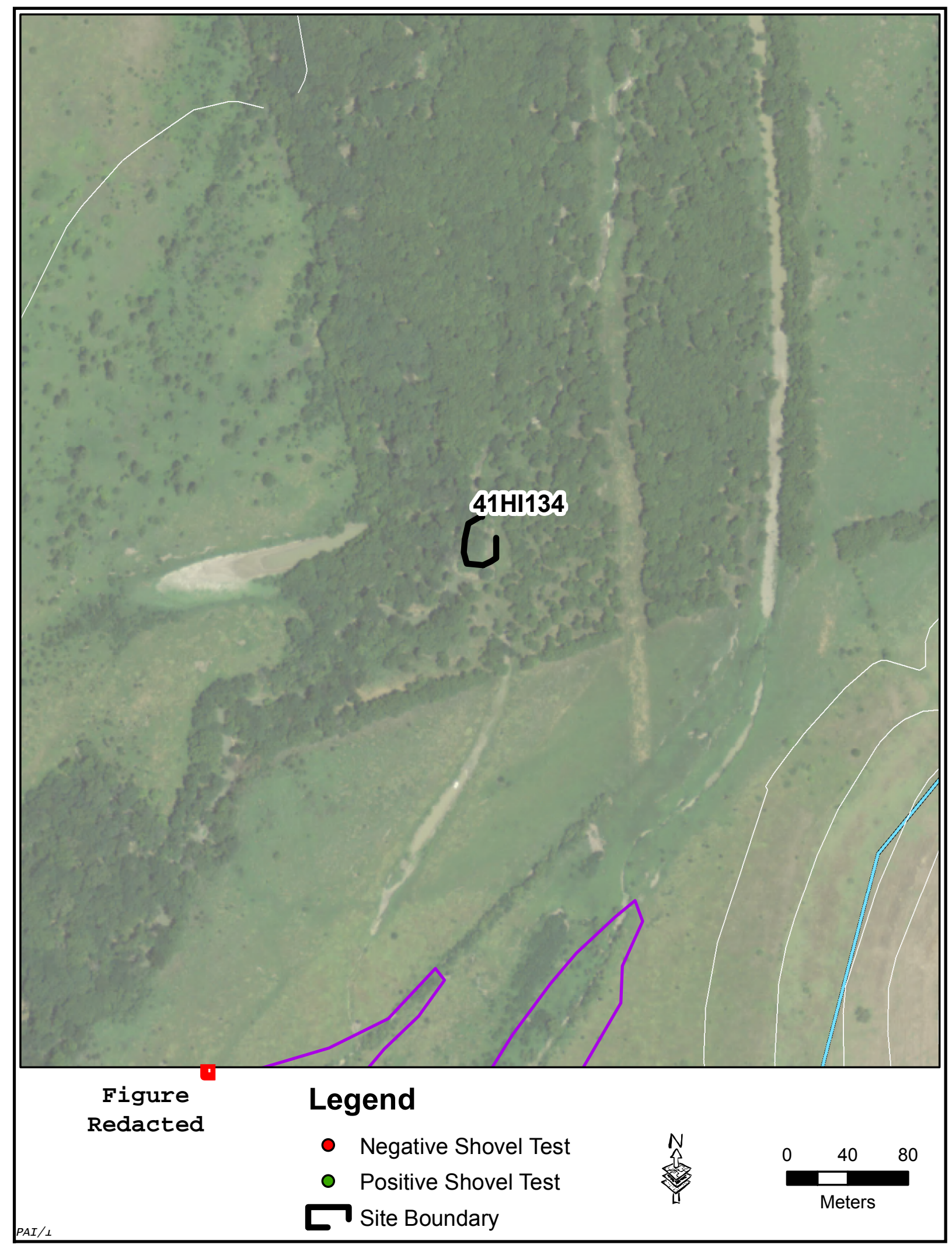

Figure 10. Map of 41HI134. 
ingham ceramic fragments, 1 stoneware fragment, and 1 snuff bottle fragment. No standing structures were observed in the vicinity.

\section{ASSESSMENT}

The site contains prehistoric and historic occupations, but more detailed ages are lacking. It is unlikely that further investigations at $41 \mathrm{HI} 135$ would yield additional information regarding the age and function of the site, due to the low density of artifacts and disturbed context. Therefore, $41 \mathrm{HI} 135$ is recommended as ineligible for listing in the National Register of Historic Places.

\section{$41 H I 136$}

\section{DESCRIPTION}

Site $41 \mathrm{HI} 136$ is a lithic resource procurement area on the upland, slope, and floodplain west of Aquilla Creek, ca. $1.2 \mathrm{~km}$ northeast of the Old School boat ramp. It was originally recorded as three sites- $\mathrm{x} 41 \mathrm{HI} 65, \mathrm{x} 41 \mathrm{HI} 69$, and x41HI70_-by Skinner and Henderson (1972:22). The sites were later combined into a single site and designated 41HI136 (Brown 1987). Currently, the remainder of the site is situated on a north-south trending ridge on the west side of the reservoir. Upon revisiting the remaining portion of the site, it was determined to be a lithic resource procurement site due to the presence of a gravel exposure. Numerous gravels and cobbles are exposed on the surface. It was difficult to get an accurate measurement of the overall size of the site, but old site maps have it mapped as being ca. $400 \mathrm{~m}$ (north to south) by $50 \mathrm{~m}$ (east to west).

\section{CULTURAL MATERIALS OBSERVED}

Two hammerstones and two tested cobbles were observed, along with an old washtub and wheelbarrow.

\section{ASSESSMENT}

Despite the presence of artifacts and naturally occurring gravels indicating that the site was a lithic procurement area, it is unlikely that further investigations at $41 \mathrm{HI} 136$ would yield significant information due to the low density of artifacts and their surficial context. Therefore, the site is recommended as ineligible for listing in the National Register of Historic Places.

\section{$41 H I 146$}

\section{DESCRIPTION}

Site $41 \mathrm{HI} 146$ is a Late Archaic open campsite and lithic scatter along a north-south trending ridge just west of Aquilla Creek. It was originally recorded as two sites $-\mathrm{x} 41 \mathrm{HI} 96$ and $\mathrm{x} 41 \mathrm{HI} 97$-by Skinner and Henderson (1972:26). The two sites were later combined into a single site and designated 41HI146 (Brown 1987). Currently, the site is on a peninsula that was created as a result of impounding Aquilla Lake (Figure 11). The site measures ca. $100 \mathrm{~m}$ (east to west) by $300 \mathrm{~m}$ (north to south) and sits $2.5 \mathrm{~km}$ north of the Old School boat ramp. Access to the peninsula was difficult, with several submerged tree stumps hidden beneath the surface of the lake and much of the shoreline covered in poison ivy, thick greenbrier, and dense brush. For these reasons, only four shovel tests were excavated onsite, three of which yielded cultural materials from the upper $20 \mathrm{~cm}$ of deposits. Due to its position on the lake, fluctuating lake levels and wave action have disturbed much of the site.

\section{CULTURAL MATERIALS OBSERVED}

Ten flakes and 2 burned rocks were recovered from shovel tests in the upper $20 \mathrm{~cm}$ of sediment. In addition, 10 flakes, a ground stone tool fragment, and 2 hammerstones were observed on the surface.

\section{ASSESSMENT}

Despite the shallow depth of the site, $41 \mathrm{HI} 146$ demonstrates a potential to have intact buried deposits based on the artifact recovery from shovel testing. Additional subsurface investigations potentially could gain significant archeological data about the remaining portion of the site. Site $41 \mathrm{HI} 46$ is recommended as potentially eligible for listing in the National Register of Historic Places. It is recommended that $41 \mathrm{HI} 146$ receive additional subsurface testing to better understand the nature of the site. 


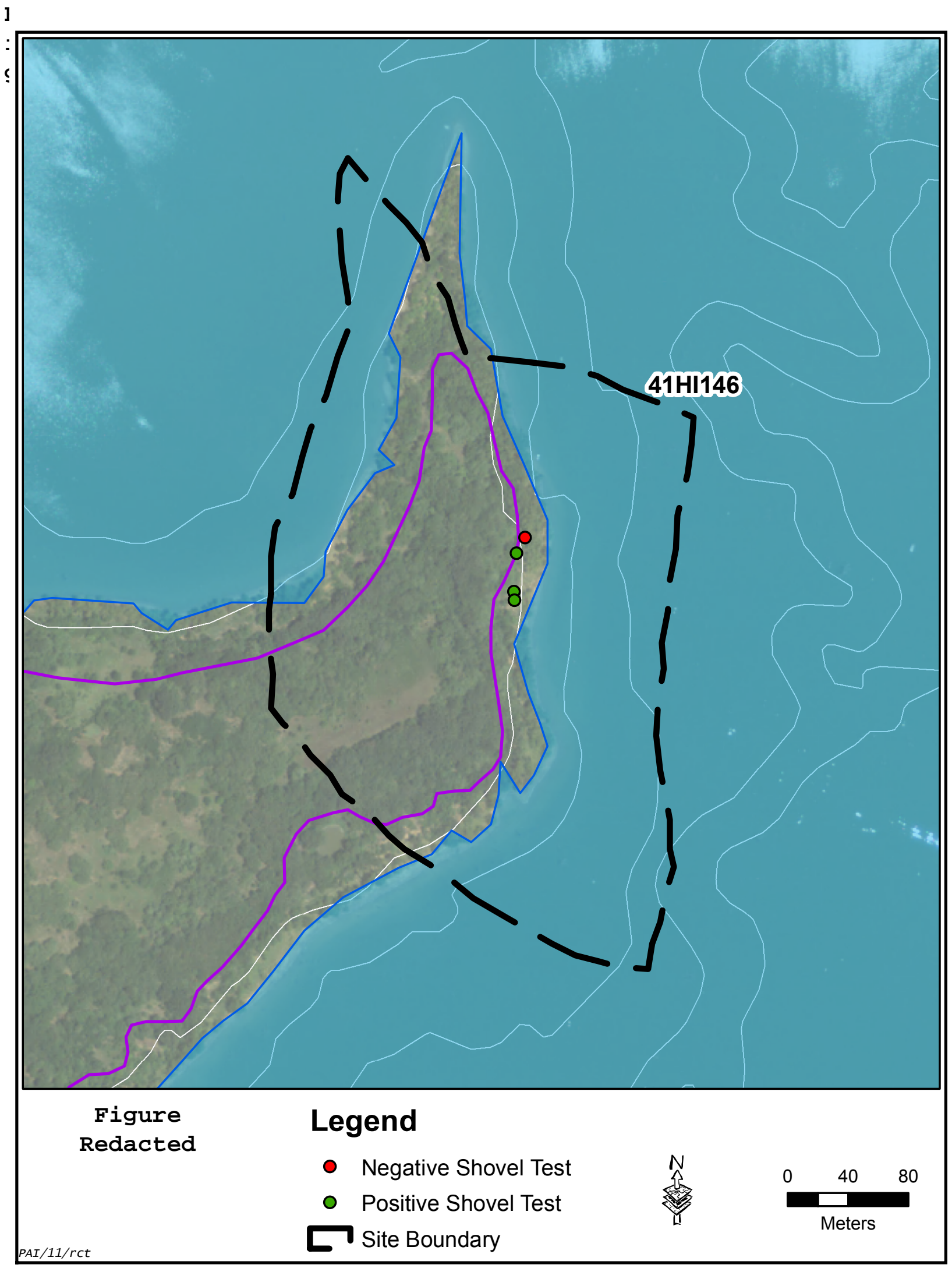

Figure 11. Map of 41HI146. 


\section{$41 H I 148$}

\section{DESCRIPTION}

Site $41 \mathrm{HI} 148$ is a lithic scatter ca. $430 \mathrm{~m}$ west/southwest of the current FM 1947 bridge crossing on the north side of Aquilla Lake. The site measures $150 \mathrm{~m}$ (north to south) by $60 \mathrm{~m}$ (east to west). It was originally recorded as x41HI124 by Skinner and Henderson (1972:30). Subsequent investigations by Brown (1987) in 1982 noted that the site was largely destroyed as a result of the construction of the current FM 1947 bridge. The current investigations noted tall grasses and small mesquite trees at the locale and confirmed that the site no longer exists.

\section{CULTURAL MATERIALS OBSERVED}

No cultural materials were observed.

\section{ASSESSMENT}

Site $41 \mathrm{HI} 148$ was destroyed during the construction of the current FM 1947 bridge. It is therefore recommended as ineligible for listing in the National Register of Historic Places.

\section{$41 H I 149$}

\section{DESCRIPTION}

Site $41 \mathrm{HI} 149$ is a prehistoric open campsite and historic farm complex near the intersection of abandoned sections of County Roads 2467 and 3440 , ca. $600 \mathrm{~m}$ west/southwest of the FM 1947 bridge crossing. It was originally recorded on the upland slope just west of Hackberry Creek (x41HI123 in Skinner and Henderson 1972:30). In 1982 investigations by the Texas Archeological Survey extended the site to the south and onto a high terrace of Hackberry Creek. This work added a historic component to the site, an early-twentieth-century farm complex. It was noted that the site was very disturbed due to erosion, with little to no soil intact.

Vegetation consists of very tall grasses and with some hackberry, elm, mesquite, and black locust trees. Three shallow shovel probes were dug to determine the nature and depth of the soil mantle. All three encountered dense, black clay sitting directly on yellowish red clay, demonstrating that the site is very shallow. No additional shovel tests were excavated.

\section{CULTURAL MATERIALS OBSERVED}

No prehistoric cultural materials were observed. The only historic materials observed were an old bed frame and a section of iron pipe. Remnants of the livestock pens mentioned on earlier site forms are present but in very poor condition.

\section{ASSESSMENT}

Because there is very little chance of this site containing intact, buried deposits, further subsurface testing is not needed. There is also little in the way of artifacts on the surface, which limits any interpretations that can be made about either site component. It is therefore recommended that $41 \mathrm{HI} 149$ be considered ineligible for listing in the National Register of Historic Places.

\section{HI150-153}

\section{DESCRIPTION}

Site $41 \mathrm{HI} 150-153$ is a lithic scatter on an eroding ridge on the east side of Aquilla Creek, ca. 450 m east of the FM 1534 bridge crossing. It was originally recorded as four small lithic scatters: 41HI150, 41HI151, 41HI152, and 41HI153 (x41HI106, x41HI107, x41HI108, x41HI109 in Skinner and Henderson 1972:28). A Late Archaic style dart point was collected from 41HI153 (x41HI109) (Skinner and Henderson 1972:28). The current investigations noted that all four of the sites are within $300 \mathrm{~m}$ of each other and occupy the same landform. Because of this, they were re-recorded as one site. Measuring $300 \mathrm{~m}$ (northwest to southeast) by $150 \mathrm{~m}$ (northeast to southwest), 41HI150-153 is one of the larger sites in the project area.

Currently, shoreline erosion from fluctuating lake levels and wave action have removed much of the sandy soil mantle, leaving many large cobbles and sandstone slabs exposed on the surface (Figure 12). As a result, no shovel tests were excavated; however, the occasional shovel probe was dug where patches of the soil mantle were intact. All revealed the thin 
nature of those patches. Vegetation throughout this area is dominated by post oak trees with the occasional juniper tree. Various short and tall grasses cover much of the ground surface. Areas along the shoreline are covered with large piles of debris, demonstrating the impact lake-level fluctuations and wave action have on this site.

\section{CULTURAL MATERIALS OBSERVED}

All cultural materials were observed on the surface of the site. Materials include 30 flakes, 4 hammerstones, and 1 biface fragment. The biface fragment is a small medial section and was not collected.

\section{ASSESSMENT}

Although prehistoric artifacts were observed at $41 \mathrm{HI} 150-153$, they were all on the surface and probably in a secondary context because there is no appreciable accumulation of sediment at this site. The potential for the site to yield significant archeological data is very low. Therefore, 41HI150-153 is recommended as ineligible for listing in the National Register of Historic Places.

\section{$41 H I 154$}

\section{DESCRIPTION}

Site $41 \mathrm{HI} 154$, an open campsite and historic artifact scatter at the end of the abandoned roadbed of County Road 2437, is now completely submerged by Aquilla Lake. It was originally recorded as two separate sites: a Late Archaic open campsite on a terrace and an upland lithic scatter just above and east of Aquilla Creek (x41HI73 and x41HI74 in Skinner and Henderson 1972:23). In 1982 investigations by the Texas Archeological Survey combined the two sites into one site designated 41HI154. Based on the most recent mapping data, $41 \mathrm{HI} 154$ is completely underwater. The area of shoreline around the site is covered with thick grasses and a mix of hardwood trees.

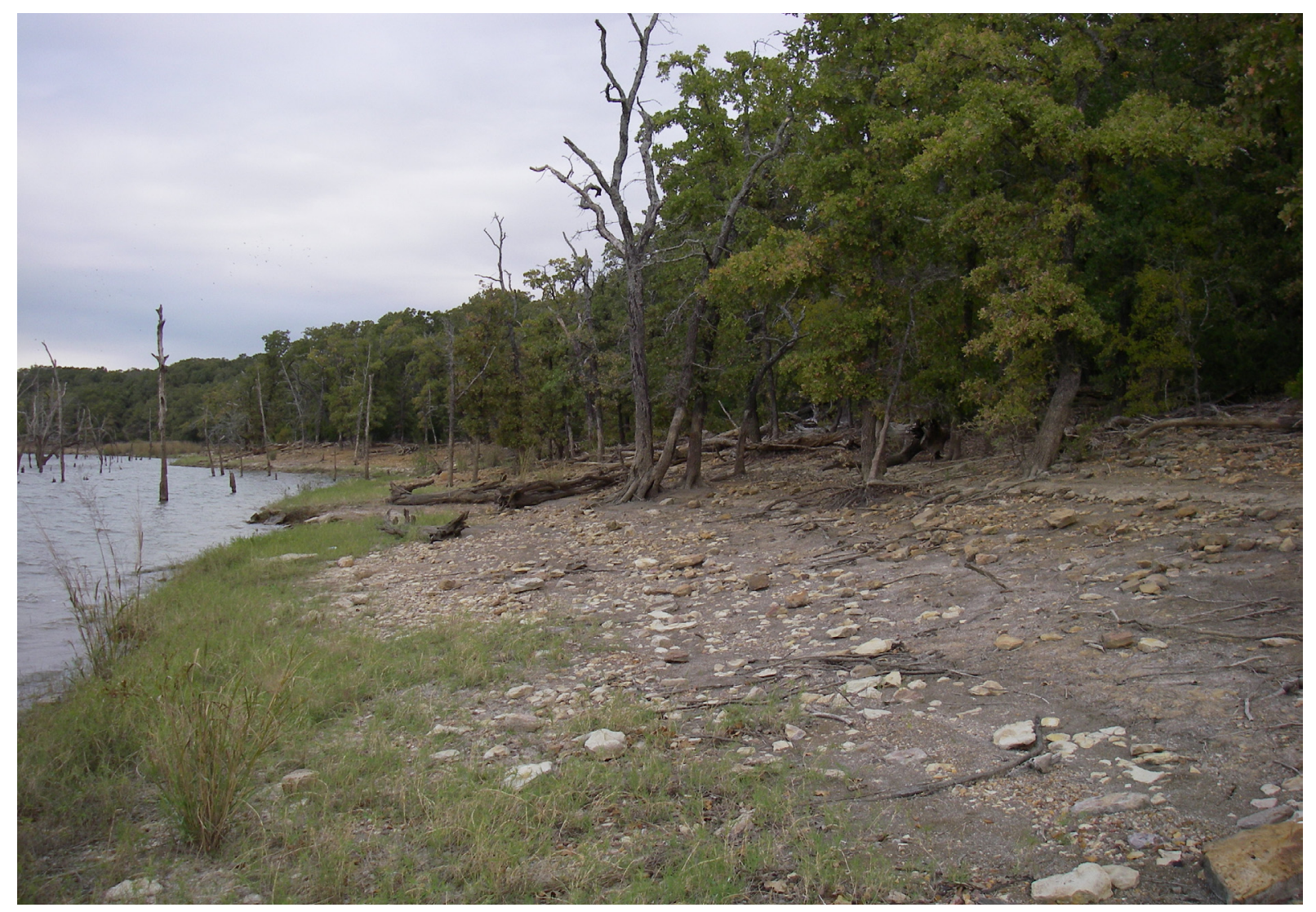

Figure 12. View of erosion within 41HI150-153, typical of most sites along the lake margins. 


\section{CULTURAL MATERIALS OBSERVED}

Just above and along the shoreline, several historic artifacts were encountered, including whiteware, glass bottle fragments, and fencing materials. Farther from the shore, an old septic tank was found in the ground that measures $3 \mathrm{ft}$ in diameter. The tank appeared to be filled with debris, so an accurate estimate of depth could not be gained. This suggests that a house was once present in the area, but other than a few bricks and the tank, no structural evidence remains.

\section{ASSESSMENT}

Due to the proximity of the historic site and the mapped location of $41 \mathrm{HI} 154$, the historic artifact scatter was incorporated into $41 \mathrm{HI} 154$, making it a multicomponent site. This expands the boundary of the site to $175 \mathrm{~m}$ (north to south) by $300 \mathrm{~m}$ (east to west). Although $41 \mathrm{HI} 154$ contains both prehistoric and historic components, the prehistoric component is underwater, and the historic component is lacking in artifacts and structures. These factors limit the potential of the site to yield significant archeological data. Site $41 \mathrm{HI} 154$ is therefore recommended as ineligible for listing in the National Register of Historic Places.

\section{$41 H I 156$}

\section{DESCRIPTION}

Site 41HI156, a Late Archaic lithic procurement site along a ridge west of Aquilla Creek (x41HI55 in Skinner and Henderson 1972:20), is now completely submerged. The site is ca. $1.15 \mathrm{~km}$ east/southeast of the Old School boat ramp. Vegetation is thin with only a few post oak trees and short grasses right at the shoreline. There is very little soil for plants to grow at this site because erosion has washed much of it off of the landform. Large wave-cut bank exposures along the shoreline demonstrate the extent of the erosion. Many large sandstone bedrock slabs, cobbles, and gravels litter the surface. As a result, no shovel tests were excavated. Dimensions of the site are unknown because most of the site is underwater, and what is above water has been completely destroyed.

\section{CULTURAL MATERIALS OBSERVED}

No cultural materials were observed.

\section{ASSESSMENT}

Due to the complete lack of artifacts and lack of a soil mantle at this site, additional investigations would yield little information. There is little to no archeological potential at 41HI156, and it is recommended that it be considered ineligible for listing in the National Register of Historic Places.

\section{$41 H I 159$}

\section{DESCRIPTION}

Site 41HI159 (x41HI125 in Skinner and Henderson 1972:30) is a small open campsite on the edge of a high terrace overlooking Hackberry Creek from the west. Investigations by Lynott and Peter (1977) consisted of limited shovel testing across the site and eight randomly placed excavation units. No subsurface cultural materials were recovered. Because very few lithic materials were recovered, and there was a large amount of secondary debris, the site was interpreted as a foraging station. Lynott and Peter (1977) acknowledged that this interpretation was somewhat biased due to the small assemblage, but they noted that with a more rigorous surface collection, this issue could be clarified.

Currently, the site is situated on the edge of open pastureland belonging to the U.S. Army Corps of Engineers, with a small clump of mesquite trees growing on the site. The eastern edge borders Aquilla Lake, and rising and falling lake levels and wave action have eroded a large portion of the site. Based on its location, it is possible that $41 \mathrm{HI} 159$ may have been impacted during the construction of the FM 1947 bridge, given that the site is only $280 \mathrm{~m}$ north of the north end of the bridge crossing. Only a small portion of the site, measuring $75 \times 75 \mathrm{~m}$, remains. A total of five shovel tests were excavated, with one yielding cultural materials. The soil mantle is very shallow, with none of the shovel tests going beyond $20 \mathrm{~cm}$ deep. 


\section{CULTURAL MATERIALS OBSERVED}

A single flake fragment and mussel shell fragments were recovered from one shovel test. No artifacts were observed on the surface or in the eroded section along the shoreline of the lake.

\section{ASSESSMENT}

The paucity of cultural materials and the lack of sediment demonstrate that much of the site has been destroyed. The potential for this site to yield significant archeological data is very low. Therefore, 41HI159 is recommended as ineligible for listing in the National Register of Historic Places.

\section{$41 H I 160$}

\section{DESCRIPTION}

Site $41 \mathrm{HI} 160$ is an open campsite and lithic scatter along a ridge overlooking Hackberry Creek from the northwest. It was originally recorded as x41HI137 by Skinner and Henderson (1972:32). Lynott and Peter (1977:39) utilized a series of shovel tests to determine site depth and dug eight test units to gain a representative sample of artifacts from the site. Only a limited variety of tools was recovered, suggesting that the site served as a foraging station (Lynott and Peter 1977:43). Currently, the site sits near the edge of Aquilla Lake ca. $1.75 \mathrm{~km}$ south of the intersection of County Roads 2431 and 2432. The landform is quite prominent with a deep erosional gully just to the east. Vegetation in the area is a dense mix of hardwoods with tall grasses and greenbrier. Four shovel tests were excavated within the site with no cultural materials recovered. None of the shovel tests went deeper than $30 \mathrm{~cm}$ because dense clay was encountered.

\section{CULTURAL MATERIALS OBSERVED}

No cultural materials were observed.

\section{ASSESSMENT}

Because no cultural materials were observed, the archeological potential of the site is very limited. As a result, $41 \mathrm{HI} 160$ is recom- mended as ineligible for listing in the National Register of Historic Places.

\section{$41 H I 162$}

\section{DESCRIPTION}

Site $41 \mathrm{HI} 162$ is a Late Archaic lithic scatter on a ridge just west of the Hackberry Creek channel. It was originally recorded as x41HI140 by Skinner and Henderson (1972:32). The site is ca. $1.45 \mathrm{~km}$ south/southeast of the intersection of County Roads 2431 and 2432. Much of the area in and surrounding the site appears to have been cleared because there is little to no soil mantle. Various thick grasses and a patchwork of mesquite trees cover the site. Dense hardwoods grow clustered closer to the lake shoreline. Eight shovel tests were excavated, with none yielding cultural materials. The deepest shovel test was $30 \mathrm{~cm}$ and that was into dense clay.

\section{CULTURAL MATERIALS OBSERVED}

No cultural materials were observed or recovered at this site.

\section{ASSESSMENT}

Disturbances due to land-clearing practices likely explain the lack of artifacts and cultural deposits at 41HI162. Due to the absence of cultural materials, disturbed contexts, and the shallow nature of the site, it is unlikely that further investigations would yield significant information. Therefore, 41HI162 is recommended as ineligible for listing in the National Register of Historic Places.

\section{$41 H I 163$}

\section{DESCRIPTION}

Site $41 \mathrm{HI} 163$ is a Late Archaic open campsite occupying a floodplain rise on the north side of Hackberry Creek. It was originally recorded as x41HI142 by Skinner and Henderson (1972:33). The site is ca. $650 \mathrm{~m}$ northwest of the U.S. Army Corps of Engineers parking area at the end of County Road 2446. The area is an old cultivated field with only a few mesquite and black locust trees and tall grasses covering the landform. Be- 
cause erosion and past plowing have disturbed the site, no shovel tests were excavated.

\section{CULTURAL MATERIALS OBSERVED}

No cultural materials were observed.

\section{ASSESSMENT}

The complete lack of artifacts, paired with the original site description of the area being a plowed field, suggests that very little, if any, of this site remains. Sandstone bedrock exposed on the surface indicates that the landform is eroded. Due to these factors, $41 \mathrm{HI} 163$ is recommended as ineligible for listing in the National Register of Historic Places.

\section{$41 H I 164$}

\section{DESCRIPTION}

Site 41HI164 was originally recorded as an open campsite on a Pleistocene terrace remnant just north of Hackberry Creek (x41HI134 in Skinner and Henderson 1972:31). The site is on what was once a cultivated field ca. $1.53 \mathrm{~km}$ west-northwest of the intersection of County Roads 2452 and 2543. Much the area is overgrown with thick, tall grasses, but only a few trees. As with many other sites in similar environmental settings, erosion has taken its toll on the area. As a result, no shovel tests were excavated.

\section{CULTURAL MATERIALS OBSERVED}

No cultural materials were observed at this site.

\section{ASSESSMENT}

Very little remains of this site as a result of erosion and twentieth-century farming activities, and no discrete cultural components can be identified. Additional testing would not yield significant archeological data. Therefore, it is recommended that $41 \mathrm{HI} 164$ be considered ineligible for listing in the National Register of Historic Places.

\section{$41 H I 169$}

\section{DESCRIPTION}

Site 41 HI169 is an open campsite on an upland divide between Hackberry Creek and an unnamed tributary. Brown (1987:I-6) noted that this site was originally recorded as $\mathrm{x} 41 \mathrm{HI} 166$ by SMU, but the location of $\mathrm{x} 41 \mathrm{HI} 166$ as depicted in Lynott and Peter (1977:32) is nowhere near the location of $41 \mathrm{HI} 169$, nor is there an SMU site form available for 41HI169 (or x41HI166) in the Texas Historical Commission's Archeological Sites Atlas. Regardless, the site sits ca. $900 \mathrm{~m}$ northeast of the U.S. Army Corps of Enginners public access parking area at the end of County Road 2446, occupying the western point of the divide between Hackberry Creek and its unnamed tributary; it overlooks the floodplain of both creeks to the north, west, and south (Figure 13). Vegetation consists of tall grasses with clusters of hardwoods, including mesquite, elm, and juniper trees. Eight shovel tests were excavated, and seven recovered cultural materials. Cultural materials were recovered from near the surface to ca. $60 \mathrm{~cm}$ below surface. Overall, the site measures approximately $100 \mathrm{~m}$ (north to south) by $200 \mathrm{~m}$ (east to west) and appears to be well preserved with buried and intact cultural deposits.

\section{CULTURAL MATERIALS OBSERVED}

A total of 36 flakes were recovered from shovel tests, as well as a gar scale, mussel shell fragments, and fragments of burned rock.

\section{ASSESSMENT}

The presence of buried and intact cultural deposits suggests that significant archeological data could be gained regarding the functional and temporal aspects of the site. Based on these factors, it is recommended that $41 \mathrm{HI} 169$ be judged potentially eligible for listing in the National Register of Historic Places. The site is above or outside of the proposed 6.5 -ft pool raise; however, if future plans were to have an adverse impact on the site, it is recommended that additional subsurface testing be conducted. 


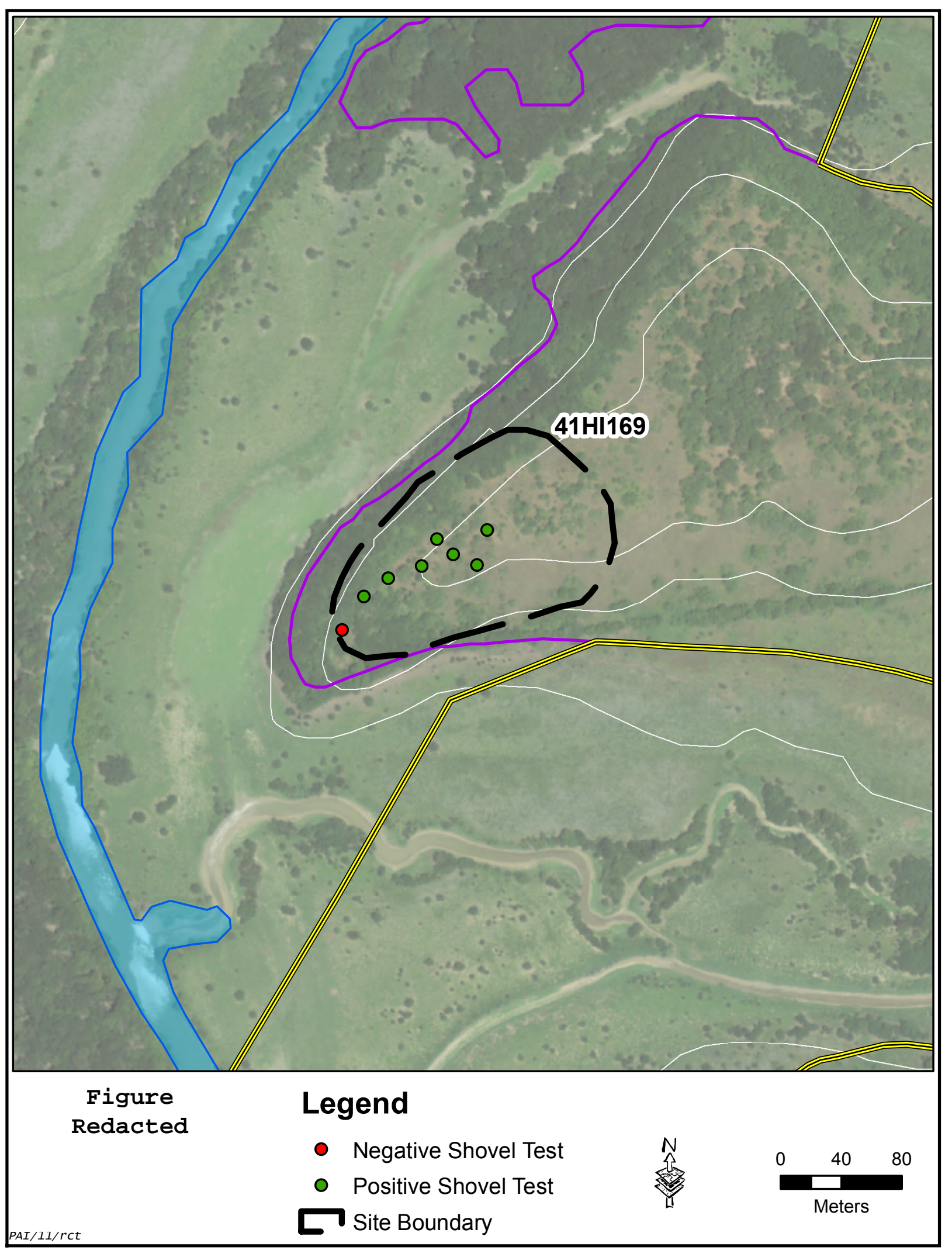

Figure 13. Map of 41HI169. 


\section{$41 H I 170$}

\section{DESCRIPTION}

Site 41HI170, an open campsite and lithic scatter on the east side of Aquilla Creek, is now submerged. It was originally recorded by the Texas Archeological Survey in 1983. The site is ca. $1.6 \mathrm{~km}$ southeast of the east end of the FM 1534 bridge crossing. Current site dimensions are unknown because the site is underwater, but previous investigations mapped the site as $50 \times 250 \mathrm{~m}$. It is possible that a small part of this site exists above the conservation pool, but if so, it is only a small, highly eroded portion. Large post oak trees grow several meters away from the shoreline, and tall, thick grasses grow closer to the water's edge. Very little of the soil mantle remains intact, and as a result, no shovel testing was conducted. In portions of the highly eroded areas, gravel outcrops are exposed on the surface, though none of the gravels appeared to be modified or tested.

\section{CULTURAL MATERIALS OBSERVED}

No cultural materials were observed.

\section{ASSESSMENT}

With the creation of the reservoir, much of the site and soil mantle that could have contained buried cultural deposits was either washed away by wave action or completely submerged. The absence of artifacts and overall lack of sediment demonstrate that very little could be learned from this site. Due to the lack of artifacts and integrity, $41 \mathrm{HI} 170$ is recommended as ineligible for listing in the National Register of Historic Places.

\section{$41 H I 171$}

\section{DESCRIPTION}

Site $41 \mathrm{HI} 171$, originally recorded as a lithic scatter on an upland slope (x41HI110 in Skinner and Henderson 1972:28), is currently underwater. Site dimensions were recorded as $50 \times 50 \mathrm{~m}$, with a few flakes found in the area. The site location is ca. $1.1 \mathrm{~km}$ southeast of the east end of the FM 1534 bridge crossing over the reservoir. Vegetation consists of post oak trees, juniper trees, thick greenbrier, and patchy grasses. The only materials observed near the site during the current investigations were exposed gravels eroding out on the surface, none of which appeared to be modified. Due to excellent surface visibility and lack of a soil mantle, no shovel tests were excavated.

\section{CULTURAL MATERIALS OBSERVED}

Because most, if not all, of the site is submerged, no cultural materials were observed.

\section{ASSESSMENT}

There is no evidence of a prehistoric site remaining at this location. If one exists, it is underwater. For this reason, $41 \mathrm{HI} 171$ is recommended as ineligible for listing of the National Register of Historic Places.

\section{$41 H I 172$}

\section{DESCRIPTION}

Site $41 \mathrm{HI} 172$ is an open campsite west of Aquilla Creek on a small upland ridge. It was originally recorded as $\mathrm{x} 41 \mathrm{HI} 100$ by Skinner and Henderson (1972:27). Lynott and Peter (1977:100) excavated 13 shovel tests to determine the subsurface nature of the site and concluded that much of the soil mantle had been removed by erosion. Due to the lack of diagnostic artifacts, a temporal designation could not be made. The limited variety of tools and low density of lithic debris suggested that the site was a foraging station (Lynott and Peter 1977:101).

The site is ca. $1.1 \mathrm{~km}$ northwest of the intersection of FM 1534 and County Road 2123. Much of the site is overgrown with small elm saplings, junipers, and oaks with greenbriers and poison ivy. A historic well was also recorded in the northwest portion of the site near a large hackberry tree, but the well was not relocated during the current investigations. A total of 12 shovel tests were excavated in and around the site to search for any buried cultural materials. Of the 12 tests, 4 recovered lithic debitage. Most of the intact portion of the site, an area measuring $15 \times 15 \mathrm{~m}$, was found within a pocket of deep sand, with cultural deposits ranging from near the surface to $80 \mathrm{~cm}$ below surface. 
Shovel tests outside of this pocket of sand only went to a depth of about $20 \mathrm{~cm}$ before encountering the clayey subsoil. Floodwaters and runoff have eroded much of the landform around the site, and wild hogs have rooted up much of the area as well.

\section{CULTURAL MATERIALS OBSERVED}

A total of 17 flakes and 1 utilized flake were recovered from the shovel tests. A fragment of burned rock was also found.

\section{ASSESSMENT}

Despite the presence of lithic debitage and intact buried deposits, the site lacks any type of diagnostic artifacts. In addition, it appears that the site lacks stratigraphy and the ability to yield discrete and meaningful components, so it is unlikely that further investigations would yield significant archeological data. Therefore, $41 \mathrm{HI} 172$ is recommended as ineligible for listing in the National Register of Historic Places.

\section{$41 H I 173$}

\section{DESCRIPTION}

Site 41HI173, originally recorded in 1977 as a lithic scatter or chipping station just east of the Aquilla Creek channel, is now submerged. A subsequent site visit by the Texas Archeological Survey in 1983 referred to this site $\mathrm{x} 41 \mathrm{HI} 169$ (Brown 1987:I-6), though the SMU site form on file refers to the site as $41 \mathrm{HI} 173$. Regardless, the site is located ca. $1.4 \mathrm{~km}$ southwest of the intersection of FM 1947 and County Road 2432 along a ridge that is currently underwater. Prior to inundation, the site was recorded as $200 \times 50 \mathrm{~m}$, following the small ridge down to the creek floodplain, but the current site dimensions are impossible to determine. Based on the current investigations, it is likely that the entire site is submerged. Tall grasses and post oak trees cover much of the landscape around the site location. Areas of the surface are highly visible and show signs of erosion, with hard-packed clayey subsoils and gravels exposed at the surface.

\section{CULTURAL MATERIALS OBSERVED}

No cultural materials were observed.

\section{ASSESSMENT}

The creation of the reservoir and subsequent wave action along the shoreline have destroyed any portion of the site that remained above the flood pool. Therefore, $41 \mathrm{HI} 173$ is recommended as ineligible for listing in the National Register of Historic Places.

\section{$41 H I 174$}

\section{DESCRIPTION}

Site 41HI174, a Late Archaic open campsite, is ca. $200 \mathrm{~m}$ east of Little Aquilla Creek. It was originally recorded as x41HI117 by Skinner and Henderson (1972:29). This site is located in the very northwest portion of the project area ca. $900 \mathrm{~m}$ southwest of the intersection of $\mathrm{SH}$ 22 and County Road 2401. The site sits on a north-south trending ridge that slopes gradually south, but a large portion of the landform appears to have been cleared mechanically. A hearth was recorded as part of the site during the previous investigations but was not seen during the current investigations. Ten shovel tests were excavated across the site, and none yielded cultural materials. The deepest shovel tests went to $35 \mathrm{~cm}$ below surface, terminating on a dense, red clayey subsoil. A small, two-track road winds through the southern portion of the site, and this is the only location where cultural materials were observed on the surface.

\section{CULTURAL MATERIALS OBSERVED}

Ten flakes were found in the tracks of the road within the site.

\section{ASSESSMENT}

The shallow nature of the site, few artifacts, the lack of buried artifacts, and disturbances demonstrate poor site integrity and a limited research potential. For these reasons, 41HI174 is recommended as ineligible for listing in the National Register of Historic Places. 


\section{$41 H I 175$}

\section{DESCRIPTION}

Site $41 \mathrm{HI} 175$ is a surface lithic scatter along the western edge of Little Aquilla Creek. It was originally reocorded as $\mathrm{x} 41 \mathrm{HI} 116$ by Skinner and Henderson (1972:29). The site is on a slight ridge ca. $650 \mathrm{~m}$ south of the intersection of $\mathrm{SH}$ 22 and County Road 2401. Vegetation consists of post oak trees, bois d'arc trees, juniper trees, greenbrier, poison ivy, and various grasses and vines. Twelve shovel tests were excavated across the site, with only three yielding cultural materials. Artifacts were recovered from just below surface to one meter deep. Soil depth throughout the area varied greatly, from 5 to $100 \mathrm{~cm}$.

\section{CULTURAL MATERIALS OBSERVED}

Three flakes were recovered from shovel tests. One flake in shovel test TN015 was found $80-100 \mathrm{~cm}$ below surface. The other flakes were from $0-20 \mathrm{~cm}$ and $20-40 \mathrm{~cm}$ below surface. No artifacts were observed on the surface.

\section{ASSESSMENT}

Variation in soil depth and thickness across the site suggests that erosion has disturbed portions of the site. Cultural materials were recovered, but in very small numbers with respect to the number of shovel tests excavated. Although some areas of the site contain intact, deep deposits, additional work would not likely yield significant archeological data because of the scarcity of artifacts. Site $41 \mathrm{HI} 175$ is therefore recommended as ineligible for listing in the National Register of Historic Places.

\section{$41 H I 180$}

\section{DESCRIPTION}

Site $41 \mathrm{HI} 180$ is a lithic scatter at the base of a slope and floodplain of Hackberry Creek. It was originally recorded as two small lithic scatters (x41HI130 and x41HI132 in Skinner and Henderson 1972:31). The site is west of Hackberry Creek and ca. $700 \mathrm{~m}$ north-northeast of the boat ramp at the end of County Road 2428. Notes from previous investigations stated that much of the area had been plowed. Cur- rently, most of the area is overgrown with small hardwood saplings, tall grasses, poison ivy, and greenbrier. Observations of the wave-cut shoreline revealed that the soil mantle is thin and eroded. Six shovel tests were excavated across the site, only two of which recovered cultural materials. Average depth of shovel tests was ca. $36 \mathrm{~cm}$.

\section{CULTURAL MATERIALS OBSERVED}

Only two flakes were recovered during shovel testing, both of which were found in the upper $20 \mathrm{~cm}$.

\section{ASSESSMENT}

Despite the presence of buried cultural materials at $41 \mathrm{HI} 180$, the distribution of these artifacts is limited and there is little appreciable sediment accumulation at the site. It is unlikely that further investigations would yield significant archeological data. Therefore, $41 \mathrm{HI} 180$ is recommended as ineligible for listing in the National Register of Historic Places.

\section{$41 H I 181$}

\section{DESCRIPTION}

Site $41 \mathrm{HI} 181$ was originally recorded as a lithic scatter along a ridge to the east of Aquilla Creek by the Texas Archeological Survey in 1983 (Brown 1987:I-6). With the creation of Aquilla Lake, the site is now situated near the shoreline of the lake, ca. $2.3 \mathrm{~km}$ north-northeast of the Old School boat ramp, although site forms and mapping data suggest that the site is under the current level of the reservoir. A small portion of the site could exist above the current lake level, but these nearshore areas are marshy, overgrown with tall grasses, and highly eroded due to wave action. These factors precluded the use of shovel tests.

\section{CULTURAL MATERIALS OBSERVED}

No cultural materials were observed.

\section{ASSESSMENT}

Due to the absence of artifacts and lack of contextual integrity, 41HI181 is recommended 
as ineligible for listing in the National Register of Historic Places.

\section{$41 H I 184$}

\section{DESCRIPTION}

Site $41 \mathrm{HI} 184$ was originally recorded as a small upland lithic scatter (x41HI59 in Skinner and Henderson 1972:21), but the original site form also states that this site was heavily disturbed by construction of a spillway, which is ca. $150 \mathrm{~m}$ north of the site. The current investigations revealed dense mesquite growth and incised gullies across the surface of the site. These characteristics suggest that the site is disturbed, probably from spillway construction. No shovel tests were excavated.

\section{CULTURAL MATERIALS OBSERVED}

No cultural materials were observed.

\section{ASSESSMENT}

Based on disturbances and the absence of artifacts, $41 \mathrm{HI} 184$ is recommended as ineligible for listing in the National Register of Historic Places.

\section{$41 H I 188$}

\section{DESCRIPTION}

Site $41 \mathrm{HI} 188$ was originally recorded as a small lithic scatter or chipping station (x41HI87 in Skinner and Henderson 1972:25). It was situated on an upland slope, an area that later served as the spillway for Aquilla Lake. As a result, $41 \mathrm{HI} 188$ was completely destroyed by spillway construction.

\section{CULTURAL MATERIALS OBSERVED}

No cultural materials were observed.

\section{ASSESSMENT}

Site $41 \mathrm{HI} 188$ was destroyed by the construction of the spillway and no longer exists. It is therefore ineligible for listing in the National Register of Historic Places.

\section{$41 H I 189$}

\section{DESCRIPTION}

Site $41 \mathrm{HI} 189$ is a Late Archaic open campsite situated east of Aquilla Creek along a north-south trending ridge. It was originally recorded as $\mathrm{x} 41 \mathrm{HI} 93$ by Skinner and Henderson (1972:26). The present location of the site is mapped right at the shoreline of the reservoir, $200 \mathrm{~m}$ north of where the old road bed for County Road 2437 meets the lake. There were no dimensions given for the site, but U.S. Army Corps of Engineer maps have the site measuring ca. $50 \mathrm{~m}$ in diameter. Vegetation consists of thick grasses and vines with mesquite trees and a few other mixed hardwoods. Because the site is located on the shoreline, erosion from wave action has washed away much of the sandy soil mantle and exposed the clayey subsoil across most of the site. As a result, no shovel tests were excavated.

\section{CULTURAL MATERIALS OBSERVED}

A single flake was found on the surface near the water's edge. In addition, a large mammalian vertebra was recovered from the surface, but it is unknown if it is related to the site's occupation.

\section{ASSESSMENT}

The lack of both cultural materials and intact soil demonstrates limited research potential and poor site integrity. Additional investigations would yield very little, if any, significant archeological data on the site. Therefore, 41HI189 is recommended as ineligible for listing in the National Register of Historic Places.

\section{$41 H I 199$}

\section{DESCRIPTION}

Based on site forms, notes, maps, and site plottings, it is not clear which SMU site is represented by 41HI199. Brown (1987:I-7) noted that $41 \mathrm{HI} 199$ may represent SMU site $\mathrm{x} 41 \mathrm{HI} 128$. Site $\mathrm{x} 41 \mathrm{HI} 128$ in Skinner and Henderson (1972:14) and the UTM coordinates for the site on the SMU site form place the site east of Hackberry Creek. The TARL and U.S. 
Army Corps of Engineers plottings for this site, however, place it ca. $1.2 \mathrm{~km}$ east of Aquilla Creek and $1.4 \mathrm{~km}$ south of the intersection of FM 1534 and FM 1947. Equally as nebulous are the characteristics of the site. The SMU and later TAS site forms detail very little about the site's size and cultural materials. The TARL and Corps plotted site location was visited during the current investigations. The locale is covered with a dense stand of post oak trees, juniper trees, greenbriers, various saplings, and some grasses. Much of the surface has been eroded, exposing numerous gravels and cobbles, resulting in excellent ground surface visibility. Many of the cobbles appear to be decent material for lithic tool production, but no culturally modified pieces were observed.

\section{CULTURAL MATERIALS OBSERVED}

No cultural materials were observed at this locale, though a small stock tank is present near the northwest boundary of the site.

\section{ASSESSMENT}

Due to the absence of archeological materials and intact soil mantle, additional testing at this site would result in very little, if any, significant archeological data. Overall, though, it is unclear if this locale was ever recorded as a site. As a result, 41HI199 is recommended as ineligible for listing in the National Register of Historic Places.

\section{$41 H I 260$}

\section{DESCRIPTION}

Prior to the current investigations, there was little to no information about 41HI260 other than a site plotting on TARL and U.S. Army Corps of Engineers maps. The Texas Historical Commission's Archeological Site Atlas has no site form for $41 \mathrm{HI} 260$ on file, although it is fairly clear based on the site number that it was not recorded by SMU or the Texas Archeological Survey. Presently, little is still known about this site. Site plottings place it on County Road 2415 ca. $100 \mathrm{~m}$ south of the old Aquilla Creek bridge, which is no longer in use. This locale was visited, and much of the area is in the floodplain of Aquilla Creek. Vegetation across the site consists of thick brush with greenbriers, poison ivy, and a mix of hardwood trees. The presence of several push piles indicates a recent disturbance to the ground surface. All of these push piles are near the Corps fence line and are likely the result of brush clearing for access purposes.

\section{CULTURAL MATERIALS OBSERVED}

Eight shovel tests were placed in and around this area. The only object recovered was a small, questionable flake that was found among flood gravels in shovel test MC001. At the southern end of the site is a trash scatter, but based on the materials observed (oil filters, sheet metal, shoes, jars, paint cans, beer bottles), it appears to be a modern or recent deposit. It is possible that this trash dump was recorded as 41HI260, but this is only speculative.

\section{ASSESSMENT}

Although designated as 41HI260, the current investigations found little to no evidence that there was ever a site at this disturbed locale. Site $41 \mathrm{HI} 260$ is recommended as ineligible for listing in the National Register of Historic Places.

\section{ASSESSMENTS AND RECOMMENDATIONS}

Of the 39 sites assessed in this report, 5 (41HI74/114, 41HI128, 41HI134, 41HI146, and $41 \mathrm{HI} 169$ ) are recommended as potentially eligible for listing in the National Register of Historic Places (under Criterion D), pending additional investigations (Table 2).

Of these five potentially eligible sites, two sites-41HI128 and 41HI169-are situated outside of the proposed 6.5-ft pool raise and will not be impacted. Although they are potentially eligible, these sites do not warrant additional investigations unless the undertakings by the U.S. Army Corps of Engineers change and will adversely impact these two sites. Site 41HI128 is an upland site overlooking the floodplain of Aquilla Creek that appears to be deeply buried in some areas. These deeply buried cultural materials could represent discrete occupations at this site. Paired with the abundant artifacts recovered from the site, more information stands to be gained on upland sites in the Aquilla Creek 
Table 2. Summary of site assessments for 39 archeological sites at Aquilla Lake

\begin{tabular}{|c|c|c|c|c|}
\hline Site No. & Site Class & $\begin{array}{c}\text { Site Type and Temporal } \\
\text { Components * }\end{array}$ & $\begin{array}{c}\text { Observed or Recovered } \\
\text { Cultural Materials }\end{array}$ & $\begin{array}{c}\text { National } \\
\text { Register } \\
\text { Assessment }\end{array}$ \\
\hline $41 \mathrm{HI} 74 / 114$ & $\begin{array}{l}\text { prehistoric/ } \\
\text { historic }\end{array}$ & $\begin{array}{l}\text { Late Archaic open } \\
\text { campsite; historic } \\
\text { artifact scatter }\end{array}$ & $\begin{array}{l}\text { ca. } 120+\text { flakes, } 2 \text { dart point } \\
\text { fragments ( } 1 \text { Godley), } 2 \text { biface } \\
\text { fragments, } 1 \text { scraper, possible } \\
\text { ground stone tool fragments, } \\
\text { burned rocks, bottle glass, } \\
\text { window glass, whiteware, } \\
\text { stoneware, nails, and bricks }\end{array}$ & $\begin{array}{l}\text { potentially } \\
\text { eligible }\end{array}$ \\
\hline $41 \mathrm{HI} 75$ & $\begin{array}{l}\text { prehistoric/ } \\
\text { historic }\end{array}$ & $\begin{array}{l}\text { Paleoindian through } \\
\text { Late Prehistoric open } \\
\text { campsite; historic house } \\
\text { site }\end{array}$ & $\begin{array}{l}21 \text { flakes, } 2 \text { hammerstones, } \\
\text { burned rocks, possible hearth, } \\
\text { bottle glass, stoneware, butter } \\
\text { churn lid fragment }\end{array}$ & ineligible \\
\hline $41 \mathrm{HI} 77$ & prehistoric & $\begin{array}{l}\text { Archaic to Late } \\
\text { Prehistoric open } \\
\text { campsite }\end{array}$ & $\begin{array}{l}\text { lithic debitage, cores, } \\
\text { hammerstones }\end{array}$ & ineligible \\
\hline 41HI107/108 & prehistoric & $\begin{array}{l}\text { Late Prehistoric lithic } \\
\text { scatter }\end{array}$ & 2 flakes & ineligible \\
\hline 41HI109/110 & prehistoric & $\begin{array}{l}\text { Paleoindian through } \\
\text { Late Prehistoric lithic } \\
\text { scatter/lithic resource } \\
\text { procurement area }\end{array}$ & lithic debitage, 1 core & ineligible \\
\hline $41 \mathrm{HI} 111$ & prehistoric & lithic scatter & $\begin{array}{l}50+\text { flakes, tested cobbles, } \\
1 \text { biface fragment }\end{array}$ & ineligible \\
\hline 41HI128 & prehistoric & $\begin{array}{l}\text { Late Archaic open } \\
\text { campsite }\end{array}$ & 60 flakes, 1 hammerstone & $\begin{array}{l}\text { potentially } \\
\text { eligible }\end{array}$ \\
\hline $41 \mathrm{HI} 131$ & prehistoric & \begin{tabular}{|l|} 
lithic resource \\
procurement area
\end{tabular} & \begin{tabular}{|l}
1 core, tested cobbles, \\
hammerstone, $<10$ flakes
\end{tabular} & ineligible \\
\hline $41 \mathrm{HI} 134$ & prehistoric & $\begin{array}{l}\text { Late Prehistoric open } \\
\text { campsite }\end{array}$ & none & $\begin{array}{l}\text { potentially } \\
\text { eligible }\end{array}$ \\
\hline $41 \mathrm{HI} 135$ & $\begin{array}{l}\text { prehistoric/ } \\
\text { historic }\end{array}$ & $\begin{array}{l}\text { open campsite/lithic } \\
\text { scatter; historic artifact } \\
\text { scatter }\end{array}$ & $\begin{array}{l}\text { burned rocks, } 5 \text { flakes, bricks, } \\
\text { glass bottle fragments, } 2 \\
\text { Rockingham ceramic } \\
\text { fragments, } 1 \text { stoneware } \\
\text { fragment, } 1 \text { snuff bottle } \\
\text { fragment }\end{array}$ & ineligible \\
\hline $41 \mathrm{HI} 136$ & prehistoric & $\begin{array}{l}\text { lithic resource } \\
\text { procurement area }\end{array}$ & $\begin{array}{l}2 \text { hammertones, } 2 \text { tested } \\
\text { cobbles }\end{array}$ & ineligible \\
\hline $41 \mathrm{HI} 146$ & prehistoric & $\begin{array}{l}\text { Late Archaic open } \\
\text { campsite/lithic scatter }\end{array}$ & $\begin{array}{l}20 \text { flakes, ground stone tool } \\
\text { fragment, } 2 \text { hammerstones, } \\
\text { burned rocks }\end{array}$ & $\begin{array}{l}\text { potentially } \\
\text { eligible }\end{array}$ \\
\hline $41 \mathrm{HI} 148$ & prehistoric & lithic scatter & none & ineligible \\
\hline $41 \mathrm{HI} 149$ & $\begin{array}{l}\text { prehistoric/ } \\
\text { historic }\end{array}$ & $\begin{array}{l}\text { open campsite/historic } \\
\text { farm complex }\end{array}$ & iron bedframe, iron pipe & ineligible \\
\hline 41HI150-153 & prehistoric & lithic scatter & $\begin{array}{l}30 \text { flakes, } 4 \text { hammerstones, } \\
1 \text { biface fragment } \\
\end{array}$ & ineligible \\
\hline $41 \mathrm{HI} 154$ & $\begin{array}{l}\text { prehistoric/ } \\
\text { historic }\end{array}$ & $\begin{array}{l}\text { Late Archaic open } \\
\text { campsite; historic } \\
\text { artifact scatter }\end{array}$ & $\begin{array}{l}\text { whiteware, glass bottle } \\
\text { fragments, wire fencing, } \\
\text { bricks, septic tank }\end{array}$ & ineligible \\
\hline 41HI156 & prehistoric & $\begin{array}{l}\text { Late Archaic lithic } \\
\text { resource procurement } \\
\text { area }\end{array}$ & none & ineligible \\
\hline 41HI159 & prehistoric & open campsite & $\begin{array}{l}1 \text { flake fragment, mussel shell } \\
\text { fragments }\end{array}$ & ineligible \\
\hline
\end{tabular}


Table 2, continued

\begin{tabular}{|c|c|c|c|c|}
\hline Site No. & Site Class & $\begin{array}{c}\text { Site Type and Temporal } \\
\text { Components * }\end{array}$ & $\begin{array}{c}\text { Observed or Recovered } \\
\text { Cultural Materials }\end{array}$ & $\begin{array}{c}\text { National } \\
\text { Register } \\
\text { Assessment } \\
\end{array}$ \\
\hline $41 \mathrm{HI} 160$ & prehistoric & $\begin{array}{l}\text { open campsite/lithic } \\
\text { scatter }\end{array}$ & none & ineligible \\
\hline 41HI162 & prehistoric & $\begin{array}{l}\text { Late Archaic lithic } \\
\text { scatter }\end{array}$ & none & ineligible \\
\hline $41 \mathrm{HI} 163$ & prehistoric & $\begin{array}{l}\text { Late Archaic open } \\
\text { campsite }\end{array}$ & none & ineligible \\
\hline $41 \mathrm{HI} 164$ & prehistoric & open campsite & none & ineligible \\
\hline $41 \mathrm{HI} 169$ & prehistoric & open campsite & $\begin{array}{l}36 \text { flakes, } 1 \text { gar scale, mussel } \\
\text { shell fragments, burned rocks }\end{array}$ & $\begin{array}{l}\text { potentially } \\
\text { eligible }\end{array}$ \\
\hline $41 \mathrm{HI} 170$ & prehistoric & $\begin{array}{l}\text { open campsite/lithic } \\
\text { scatter }\end{array}$ & None & ineligible \\
\hline $41 \mathrm{HI} 171$ & prehistoric & lithic scatter & None & ineligible \\
\hline $41 \mathrm{HI} 172$ & prehistoric & open campsite & $\begin{array}{l}17 \text { flakes, } 1 \text { utilized flake, } \\
\text { burned rock }\end{array}$ & ineligible \\
\hline $41 \mathrm{HI} 173$ & prehistoric & lithic scatter & none & ineligible \\
\hline $41 \mathrm{HI} 174$ & prehistoric & $\begin{array}{l}\text { Late Archaic open } \\
\text { campsite }\end{array}$ & 10 flakes & ineligible \\
\hline $41 \mathrm{HI} 175$ & prehistoric & lithic scatter & 3 flakes & ineligible \\
\hline $41 \mathrm{HI} 180$ & prehistoric & lithic scatter & 2 flakes & ineligible \\
\hline $41 \mathrm{HI} 181$ & prehistoric & lithic scatter & none & ineligible \\
\hline $41 \mathrm{HI} 184$ & prehistoric & lithic scatter & none & ineligible \\
\hline $41 \mathrm{HI} 188$ & prehistoric & lithic scatter & none & ineligible \\
\hline $41 \mathrm{HI} 189$ & prehistoric & $\begin{array}{l}\text { Late Archaic open } \\
\text { campsite }\end{array}$ & 1 flake, 1 mammalian vertebra & ineligible \\
\hline $41 \mathrm{HI} 199$ & prehistoric & lithic scatter? & none & ineligible \\
\hline $41 \mathrm{HI} 260$ & historic? & $\begin{array}{l}\text { possible historic artifact } \\
\text { scatter }\end{array}$ & $\begin{array}{l}1 \text { flake, mid- to late-20th- } \\
\text { century trash dump }\end{array}$ & ineligible \\
\hline $41 \mathrm{HI} 310$ & prehistoric & lithic scatter & $\begin{array}{l}\text { lithic debitage, hammerstone, } \\
\text { core, possible ground stone tool } \\
\text { fragment, solarized glass } \\
\text { fragment }\end{array}$ & ineligible \\
\hline $41 \mathrm{HI} 311$ & prehistoric & lithic scatter & $\begin{array}{l}3 \text { flakes, } 2 \text { battered stones, } \\
1 \text { tested cobble }\end{array}$ & ineligible \\
\hline $41 \mathrm{HI} 312$ & historic & hand-dug well & $\begin{array}{l}\text { corrugated sheet metal, milled } \\
\text { lumber, wire fencing }\end{array}$ & ineligible \\
\hline
\end{tabular}

* Temporal components are based on the recovery of diagnostic artifacts from current and previous investigations. 
basin. Another upland site is $41 \mathrm{HI} 169$. The prominent landform the site occupies contains a relatively shallow or thin soil mantle, but artifact recovery within that zone was abundant across the site. Additional testing at this site could yield information about upland sites along Hackberry Creek.

The remaining three sites-41HI74/114, 41HI134, and 41HIHI146-will be impacted by the pool raise and therefore should receive additional subsurface testing to determine their eligibility for listing in the National Register of Historic Places. Site 41HI74/114 contains many buried artifacts and possible buried features, such as hearths, based on burned rocks recovered from several shovel tests. Site 41HI134 is a floodplain site in danger of being inundated by the proposed lake level raise. Previous investigations recommended that mechanical trenching take place at this site because of the possibly of deeply buried deposits. Because a Caddo sherd and lithic artifacts were recovered here from a cutbank exposure during the initial investigations in the 1970 s, subsurface testing should be conducted to determine if deposits are intact and discrete. Information obtained at this site could add to the knowledge of Late Prehistoric occupations along the Hackberry Creek floodplain. Although only upland remnants of 41HI146 remain, shovel testing and surface observations yielded many flakes and possible ground stone tools. Additional subsurface testing at this site could yield much more information on prehistoric Native American use of Aquilla Creek.

The other 34 sites are considered ineligible for National Register listing because they either lack cultural materials altogether or lack buried cultural materials from isolated, well-defined components. In many cases, these sites have been disturbed or destroyed by erosion and the creation of Aquilla Lake, and artifacts are so sparse that the sites cannot be interpreted with any confidence. Therefore, they do not have the capacity to yield information important for understanding the prehistory of the region, and it is recommended that no further archeological work be required. 


\section{REFERENCES CITED}

Anonymous

2011 Find A Grave, s.v. "Lamento [sic] Cato." Electronic document, http://www.findagrave. $\mathrm{com} /$ cgi-bin/fg.cgi?page $=$ gr \&GSln $=$ cato $\& \mathrm{G}$ Sbyrel=all\&GSdyrel=all\&GSst $=46 \& G S c n t$ $\mathrm{y}=2674 \&$ GSentry $=4 \&$ GSob $=$ n\&GRid $=6442$ 9241\&df=all\&, accessed May 23, 2012.

Arnn, John W. III, and E. Frances Gadus 1999 Archeological Survey and Geomorphological Assessment of a 31-Mile Pipeline Route, Aquilla Lake to the City of Cleburne. Technical Reports No. 42. Prewitt and Associates, Inc., Austin.

Austin, Kenneth E.

2011 Handbook of Texas Online. Electronic document, http://www.tshaonline. org/handbook/online/articles/hch15, accessed January 14, 2011.

Barnes, Virgil E.

1979 Geologic Atlas of Texas, Waco Sheet. Bureau of Economic Geology, The University of Texas at Austin.

Blair, Frank

1950 The Biotic Provinces of Texas. The Texas Journal of Science 2(1):93-117.

Brooks, Charles A.

1978 Soil Survey of Hill County, Texas. U.S. Department of Agriculture, Soil Conservation Service, in cooperation with Texas Agricultural Experiment Station.

Brown, David O.

1987 Archeology at Aquilla Lake: 1978-1982 Investigations. 3 vols. Research Report 81. Texas Archeological Survey, The University of Texas at Austin.

Bryan, Frank

1930 Archeological Remains in the Black and Grand Prairies of Texas. Bulletin of the Texas Archeological and Paleontological Society 2:76-84.

1931 Notes on the Archeology of Central Texas. American Anthropologist 33(1):16-31.
1937 A Preliminary Report on the Archeology of Western Navarro County and Some Camp Sites in Hill and McLennan County. Central Texas Archeologist 3:70-79.

Bureau of Vital Statistics

n.d. Texas Death Records, s.v. "Nicklos [sic] Harvey Harvick." State Registrar Office, Austin. Electronic document, https://familysearch.org/pal:/MM9.1.1/JDY8-S3D, accessed June 5, 2012.

Collins, Michael B.

1995 Forty Years of Archeology in Central Texas. Bulletin of the Texas Archeological Society 66:361-400.

Collins, Michael B., and Vance T. Holliday

1985 Geoarchaeology of the Lower Bosque Basin, McLennan County, Texas. Report submitted to the U.S. Army Corps of Engineers, Fort Worth, District.

Dorrycott, Tim, and Gail Dorrycott

2009 Find A Grave, s.v. "Cincinnati N. Harvick." Electronic document, http://www. findagrave.com/cgi- http://www.findagrave. com/cgi-bin/fg.cgi?page=gr\&GSln=harvick $\&$ GSfn=cincinnati\&GSbyrel=all\&GSdyrel $=$ all $\&$ GSob=n\&GRid=44838887\&df=all $\&$, accessed May 14, 2012.

Duffield, Lathel F.

1959 Appraisal of the Archeological Resources of Waco Lake, McLennan County, Texas. Report submitted to the National Park Service by the Texas Archeological Salvage Project, The University of Texas at Austin.

Hayward, O. T., Peter M. Allen, and David L. Amsbury

1996 Lampasas Cut Plain: Episodic Development of an Ancient and Complex Regional Landscape, Central Texas. In Friends of the Pleistocene Field Trip 1996 South-Central Cell Guide Book. Published by Friends of the Pleistocene and Department of Anthropology, Texas A\&M University, College Station. 
Hill County

Ad Valorem Tax Records. Texas State Library and Archives Commission, Austin.

Deed Records. Hill County Clerk, Hillsboro.

Probate Minutes. Hill County Clerk, Hillsboro.

Hill, Robert T.

1900 Geography and Geology of the Black and Grand Prairies, Texas. Twenty First Annual Report of the United States Geological Survey, Part VII - Texas (1899-1900). U.S. Geological Survey, Washington, D.C.

Hood, Bertha

2012 Find A Grave, s.v. "Hampton J. Harvick." Electronic document, http://www.findagrave.com/cgi-bin/fg.cgi?page $=$ gr\&GSln $=$ ha rvick\&GSfn=h\&GSmn=j\&GSbyrel=all \&G Sdyrel=all\&GSob=n\&GRid=85834812\&df $=$ all $\&$, accessed May 14, 2012.

Jackson, Ron V.

1999 Texas Census, 1820-1890. Ancestry.com, subscription database, accessed April 30, 2012.

Jelks, Edward B.

1953 Excavations at Blum Rockshelter. Bulletin of the Texas Archeological and Paleontological Society 24:189-207.

1962 The Kyle Site:A Stratified Central Texas Aspect Site in Hill County, Texas. Archeology Series No. 5. Department of Anthropology, The University of Texas at Austin.

Johnson, Leroy, and Glenn T. Goode

1994 A New Try at Dating and Characterizing Holocene Climates, As Well as Archeological Periods, on the Eastern Edwards Plateau. Bulletin of the Texas Archeological Society 65:1-51.

Jurney, David H.

1988 Early Historic Vegetation Zones. In Historic Farming on the Hogwallow Prairies, Joe Pool Lake Archaeological Project, Vol. 2, compiled by David H. Jurney, Susan A. Lebo, and Melissa M. Green, pp. 333-352. Archaeology Research Program, Institute for the Study of Earth and Man, Southern Methodist University, Dallas.
Lewis Publishing Company, The

1893 A Memorial and Biographical History of McLennan, Falls, Bell, and Coryell Counties, Texas. The Lewis Publishing Company, Chicago.

Lynott, Mark J., and Duane E. Peter

1977 Archeological Investigations at Aquilla Lake, 1975. Research Report 102. Archaeology Research Program, Southern Methodist University, Dallas.

Mehalchick, Gemma, and Karl W. Kibler

2008 Hunters and Gatherers in the North Bosque River Valley: Excavations at the Baylor, Britton, McMillan, and Higginbotham Sites, Waco Lake, McLennan County, Texas. Reports of Investigations No. 156. Prewitt and Associates, Inc., Austin.

Moore, Stephen L.

2006 Savage Frontier, Volume II, 1838-1839: Rangers, Riflemen, and Indian Wars in Texas. University of North Texas Press, Denton.

Natural Fibers Information Center

1987 The Climates of Texas Counties. Bureau of Business Research, in cooperation with the Office of the State Climatologist, Texas A\&M University, and The University of Texas at Austin.

Nunley, Parker

1977 Archeological and Historical Survey of Thirteen Proposed Floodwater Retarding Structures in the Aquilla Creek Watershed, Hill County, Texas and the McClellan Creek Watershed, Carson and Gray Counties, Texas. Nunley Multimedia Productions, Dallas.

Prewitt, Elton R.

1981 Cultural Chronology in Central Texas. Bulletin of the Texas Archeological Society 52:65-89.

1985 From Circleville to Toyah: Comments on Central Texas Chronology. Bulletin of the Texas Archeological Society 54:201-238.

Prikryl, Daniel J., and Jack M. Jackson

1985 Waco Lake, McLennan County, Texas: An Inventory and Assessment of Cultural Resources. Reports of Investigations No. 39. Prewitt and Associates, Inc., Austin. 
Prikryl, Daniel J., and Elton R. Prewitt

1984 An Overview of the Native American Cultural Resources at Waco Lake, McLennan County, Texas. Letter Report No. 278. Prewitt and Associates, Inc., Austin.

Rootsweb

2012 Ridge Park Cemetery [Sa]. Electronic document, http://www. rootsweb.ancestry.com/ txhcgs/ RidgeParkSa.htm, accessed May 14, 2012.

Scott, Ann M.

1998 Archeological Survey of the Proposed Aquilla Water Supply Project Pump Station, Hill County, Texas. Letter Report No. 418. Prewitt and Associates, Inc., Austin.

Shelley, Cathy Creger

2006 Find A Grave, s.v. "Marian Elizabeth Shoemaker Horn." Electronic document, http://www.findagrave.com/cgi-bin/fg.cgi ?page $=$ gr \&GSln $=$ horn $\&$ GSfn $=$ marian $\&$ GSbyrel $=$ all $\&$ GSdyrel $=$ all $\&$ GSst $=46 \& G$ Scnty $=2628 \&$ GSentry $=4 \&$ GSob=n $\&$ GR $\mathrm{id}=15502718 \& \mathrm{df}=$ all $\&$, accessed May 14 , 2012.

Simmons, Frank E.

1965 The History of Coryell County. Dayton Kelly, Belton.

Skinner, S. Alan, and Mark L. Henderson

1972 Archeological Resources of the Aquilla Lake Watershed. In The Natural and Cultural Environmental Resources of Aquilla Lake Watershed, Hill County, Texas, assembled by S. Alan Skinner, pp. 3-62. Institute for the Study of Earth and Man, Southern Methodist University, Dallas.

Skinner, S. Alan, C. Shaw, K. Huckaby, and M. L. Bartsch

1978 An Evaluation of Archeological Research at Aquilla Lake. Archaeology Research Program, Southern Methodist University, Dallas.

Stephenson, Robert L.

1947 Archeological Survey of Whitney Basin: A Preliminary Report. Bulletin of the Texas Archeological and Paleontological Society 18:129-142.

1970 Archeological Investigations in the Whitney Reservoir Area, Central Texas. Bulletin of the Texas Archeological Society 41:37-277.
Story, Dee Ann, and Harry J. Shafer

19651964 Excavations at Waco Reservoir, McLennan County, Texas: The Baylor and Britton Sites. Miscellaneous Papers No. 6. Texas Archeological Salvage Project, The University of Texas at Austin.

St. Romain, Lillian Schiller

1951 Western Falls County, Texas. Texas State Historical Association, Austin.

Suhm, Dee Ann

1960 A Review of Central Texas Archeology. Bulletin of the Texas Archeological Society 29:63-107.

Texas Department of Health

1911 Texas Death Indexes, 1903-2000. Texas Department of Health, State Vital Statistics Unit, Austin. Electronic document, available from http://search.ancestry.com/iexec? $\mathrm{htx}=$ View \&r=an\&dbid=4876\&iid=txdth _19031940s-1034\&fn=L.+F.\&ln=Shoema ker\&st $=$ r\&ssrc $=\&$ pid $=4368567$, accessed Mary 21, 2012.

Texas General Land Office

1838 Clerk Returns from Milam County, Texas, February 1838, File 1. Texas General Land Office, Austin.

1848 Michael D. Castleman Survey (320 acres), Hill County. Robertson District, Bounty Warrant, File 298, Abstract 181, Patented on June 8, 1848, to Thomas Dillard. Texas General Land Office, Austin.

1854 Michael D. Castleman Survey (1,280 acres), Hill County. Robertson District, Bounty Warrant, File 615, Abstract 189. Patented on February 23, 1854, to Michael D. Castleman. Texas General Land Office, Austin.

1858 Heirs of Michael D. Castleman Application for Land, Court of Claims, File 1405. Filed for the heirs of Michael D. Castleman on August 9, 1858, Texas General Land Office, Austin.

Tobin International

1938 Hill County, aerial photograph, frame 21093-77, January 18, 1938. Available from P2 Energy Solutions, San Antonio.

Tyler, George W.

1936 The History of Bell County. Naylor Press, San Antonio. 
University of Alabama

1903 Catalogue of the University of Alabama for Academic year, 1902-1903. Brown Printing Company, Montgomery.

U.S. Army Map Service

1952 Hill County, aerial photograph, frame 119, November 20, 1952. Available from U.S. Geological Survey, http://earthexplorer. usgs.gov/, accessed April 4, 2012.

U.S. Department of Commerce, Bureau of the Census

1920a Ellis County, manuscript population schedule. Heritage Quest Online, subscription database, accessed June 5, 2012.

1920b Hill County, manuscript population schedule. Heritage Quest Online, subscription database, accessed June 5, 2012.

1930 Hill County, manuscript population schedule. Heritage Quest Online, subscription database, accessed June 5, 2012.

U.S. Department of Commerce and Labor, Bureau of the Census

1910a Hill County, manuscript population schedule. Heritage Quest Online, subscription database, accessed June 5, 2012.

1910b Ellis County, manuscript population schedule. Heritage Quest Online, subscription database, accessed June 5, 2012.

U.S. Department of the Interior, Census Office

1850 Limestone County, manuscript population schedule. Heritage Quest Online, subscription database, accessed April 30, 2012.

1860a Hill County, manuscript population schedule. Heritage Quest Online, subscription database, accessed May 14, 2012.

1860b Hill County, manuscript slave schedule. Heritage Quest Online, subscription database, accessed May 14, 2012.

1860c Hill County, manuscript agricultural schedule. Texas State Library and Archives Commission, Austin.

1870a Hill County, manuscript population schedule. Heritage Quest Online, subscription database, accessed May 14, 2012. 1870b Hill County, manuscript agricultural schedule. Texas State Library and Archives Commission, Austin.

1880a Hill County, manuscript population schedule. Heritage Quest Online, subscription database, accessed May 14, 2012.

1880b Hill County, manuscript agricultural schedule. Heritage Quest Online, subscription database, accessed May 14, 2012.

1900 Hill County, manuscript population schedule. Heritage Quest Online, subscription database, accessed May 14, 2012.

U.S. Geological Survey

1975 Hill County, aerial photograph, frame 23, February 1, 1975. Available from U.S. Geological Survey, http://earthexplorer.usgs. gov/, accessed April 4, 2012.

War Department Collection of Confederate Records n.d. Index to Compiled Service Records of Confederate Soldiers Who Served in Organizations From the State of Texas, s.v. "Hampton Harvick." Electronic document, https://familysearch.org/pal:/MM9.1.1/ FSNB-NP6, accessed June 5, 2012.

Warren, James E.

1977 Survey and Testing within the Little Aquilla Creek Watershed for the Soil Conservation Service, Temple, Texas. Report on file at the Texas Historical Commission, Austin.

Watt, Frank H.

1938 The Waco Sinker. Central Texas Archeologist 4:21-70.

Whitener, Donald B.

2010 FindAGrave,s.v."FlorenceBellJohnsonShoemaker." Electronic document, http://www. findagrave.com/cgi-bin/fg.cgi?page=gr\&G Sln=shoemaker \&GSfn=florence $\&$ GSmn $=$ bell\&GSbyrel=all\&GSdyrel=all\&GSob=n $\&$ GRid=51702590\&df=all\&, accessed May $14,2012$.

Williams, Villamae, editor

1996 Stephen F. Austin's Register of Families. Original n.p., n.p., 1984; reprinted 1989, Genealogical Publishing Company, Inc., Baltimore; reprinted 1996, Genealogical Publishing Company, Inc., Baltimore, for Clearfield Company, Inc., Baltimore. 

APPENDIX: Shovel Test Results 
Table A.1. Shovel test results

\begin{tabular}{|c|c|c|c|}
\hline Site & Shovel Test & Depth $(\mathrm{cm})$ & Materials Recovered \\
\hline \multicolumn{4}{|c|}{ Onsite Shovel Tests: } \\
\hline \multicolumn{4}{|l|}{$41 \mathrm{HI} 74 / 114$} \\
\hline & $\mathrm{MC023}$ & 35 & $\begin{array}{l}\text { 0-20 cm: } 4 \text { flakes, burned rocks } \\
20-35 \mathrm{~cm}: 3 \text { flakes, } 1 \text { gar scale, } 1 \text { Godley point base }\end{array}$ \\
\hline & $\mathrm{MC024}$ & 30 & $\begin{array}{l}0-20 \mathrm{~cm}: 2 \text { flakes } \\
20-30 \mathrm{~cm}: 1 \text { flake } \\
\end{array}$ \\
\hline & $\mathrm{MC025}$ & 40 & $\begin{array}{l}\text { 0-20 cm: } 11 \text { flakes } \\
20-4011 \text { flakes, burned rocks }\end{array}$ \\
\hline & $\mathrm{MC026}$ & 30 & $\begin{array}{l}\text { 0-20 cm: } 7 \text { flakes, burned rocks } \\
20-30 \mathrm{~cm}: 1 \text { burned flake }\end{array}$ \\
\hline & $\mathrm{MC} 027$ & 85 & $\begin{array}{l}0-20 \mathrm{~cm}: 5 \text { flakes, } 1 \text { glass } \\
20-40 \mathrm{~cm}: 4 \text { flakes, } 2 \text { glass, } 1 \text { bone } \\
40-60 \mathrm{~cm}: 19 \text { flakes, } 1 \text { glass } \\
60-80 \mathrm{~cm}: 8 \text { flakes, burned rock } \\
\end{array}$ \\
\hline & $\mathrm{MC028}$ & 80 & $\begin{array}{l}0-20 \mathrm{~cm}: 4 \text { flakes, } 4 \text { metal fragments, } 2 \text { nails, } 1 \text { glass } \\
20-40 \mathrm{~cm}: 2 \text { metal fragments, } 5 \text { flakes, } 2 \text { whiteware } \\
40-60 \mathrm{~cm}: 3 \text { metal fragments, } 1 \text { whiteware, } 1 \text { flake } \\
60-80 \mathrm{~cm}: 5 \text { flakes, } 1 \text { wire nail }\end{array}$ \\
\hline & MC029 & 100 & $\begin{array}{l}0-20 \mathrm{~cm}: 1 \text { window glass fragment, } 1 \text { bottle glass fragment, } \\
1 \text { flake } \\
20-40 \mathrm{~cm}: 3 \text { flakes, } 1 \text { whiteware, } 1 \text { brown glass fragment } \\
40-60 \mathrm{~cm}: 3 \text { flakes } \\
60-80 \mathrm{~cm}: 4 \text { flakes, } 1 \text { projectile point distal fragment, } \\
\text { burned rocks } \\
80-100 \mathrm{~cm}: 3 \text { flakes, possible ground stone }\end{array}$ \\
\hline & MC030 & 30 & $\begin{array}{l}\text { 0-20 cm: } 4 \text { flakes, } 1 \text { biface, } 4 \text { glass frgments, } 3 \text { nails, } \\
\text { burned rocks } \\
20-30 \mathrm{~cm}: 1 \text { flake, } 1 \text { cut nail }\end{array}$ \\
\hline & $\mathrm{MC} 031$ & 70 & $\begin{array}{l}0-20 \mathrm{~cm}: 5 \text { flakes, } 1 \text { nail fragment, } 1 \text { brown glass fragment } \\
20-40 \mathrm{~cm}: 1 \text { possible ground stone } \\
40-60 \mathrm{~cm}: \text { burned rocks }\end{array}$ \\
\hline & MC032 & 55 & $\begin{array}{l}0-20 \mathrm{~cm}: 5 \text { flakes } \\
40-55 \mathrm{~cm}: 2 \text { flakes }\end{array}$ \\
\hline \multicolumn{4}{|l|}{$41 \mathrm{HI} 75$} \\
\hline & TN007 & 20 & 0-20 cm: 1 flake, 2 glass \\
\hline & TN008 & 20 & 0-20 cm: 5 flakes \\
\hline & TN009 & 20 & 0-20 cm: 2 flakes, burned rock \\
\hline & TN010 & 10 & None \\
\hline & MC009 & 20 & 0-20 cm: 4 flakes, 2 glass \\
\hline & MC010 & 20 & 0-20 cm: 4 flakes, 1 glass \\
\hline \multicolumn{4}{|l|}{ 41HI107/108 } \\
\hline & TN040 & 20 & None \\
\hline & TN041 & 30 & None \\
\hline & TN042 & 30 & $\begin{array}{l}0-20 \mathrm{~cm}: 1 \text { flake } \\
20-30 \mathrm{~cm}: 1 \text { flake }\end{array}$ \\
\hline & TN043 & 20 & None \\
\hline & MC052 & 30 & None \\
\hline & MC053 & 30 & None \\
\hline & MC054 & 25 & None \\
\hline & MC055 & 35 & None \\
\hline \multicolumn{4}{|l|}{$41 \mathrm{HI} 109 / 110$} \\
\hline & MC013 & 15 & None \\
\hline
\end{tabular}


Table A.1, continued

\begin{tabular}{|c|c|c|c|}
\hline Site & Shovel Test & $\operatorname{Depth}(\mathrm{cm})$ & Materials Recovered \\
\hline & MC014 & 10 & 0-10 cm: 1 flake \\
\hline \multicolumn{4}{|l|}{$41 \mathrm{HI} 111$} \\
\hline & MC015 & 40 & $\begin{array}{l}0-20 \mathrm{~cm}: 1 \text { flake } \\
20-40 \mathrm{~cm}: 1 \text { flake }\end{array}$ \\
\hline \multicolumn{4}{|l|}{$41 \mathrm{HI} 128$} \\
\hline & TN005 & 70 & $40-60 \mathrm{~cm}: 1$ burned flake \\
\hline & TN006 & 90 & $\begin{array}{l}\text { 0-20 cm: } 1 \text { flake } \\
40-60 \mathrm{~cm}: 1 \text { flake } \\
60-80 \mathrm{~cm}: 2 \text { flakes } \\
80-90 \mathrm{~cm}: 2 \text { flakes }\end{array}$ \\
\hline & TN056 & 50 & $\begin{array}{l}0-20 \mathrm{~cm}: 6 \text { flakes } \\
20-40 \mathrm{~cm}: 4 \text { flakes }\end{array}$ \\
\hline & TN057 & 30 & $\begin{array}{l}0-20 \mathrm{~cm}: 2 \text { fence staples, } 2 \text { flakes } \\
20-30 \mathrm{~cm}: 1 \text { flake }\end{array}$ \\
\hline & TN058 & 10 & 0-10 cm: 2 flakes \\
\hline & TN059 & 35 & 0-20 cm: 4 flakes \\
\hline & TN060 & 50 & $\begin{array}{l}0-20 \mathrm{~cm}: 4 \text { flakes } \\
20-40 \mathrm{~cm}: 1 \text { flake }\end{array}$ \\
\hline & TN061 & 35 & 0-20 cm: 3 flakes \\
\hline & TN062 & 55 & $\begin{array}{l}20-40 \mathrm{~cm}: 4 \text { flakes } \\
40-55 \mathrm{~cm}: 2 \text { flakes }\end{array}$ \\
\hline & TN063 & 75 & $\begin{array}{l}20-40 \mathrm{~cm}: 4 \text { flakes } \\
40-60 \mathrm{~cm}: 2 \text { flakes } \\
60-75 \mathrm{~cm}: 2 \text { flakes }\end{array}$ \\
\hline & MC005 & 30 & $20-30 \mathrm{~cm}: 1$ flake \\
\hline & MC006 & 25 & None \\
\hline & MC007 & 10 & None \\
\hline & $\mathrm{MC008}$ & 60 & $\begin{array}{l}0-20 \mathrm{~cm}: 2 \text { flakes } \\
20-40 \mathrm{~cm}: 1 \text { flake } \\
40-60 \mathrm{~cm}: 1 \text { flake }\end{array}$ \\
\hline & MC067 & 30 & None \\
\hline & MC068 & 50 & $\begin{array}{l}0-20 \mathrm{~cm}: 1 \text { flake } \\
20-40 \mathrm{~cm}: 2 \text { flakes }\end{array}$ \\
\hline & MC069 & 55 & $\begin{array}{l}020 \mathrm{~cm}: 1 \text { flake } \\
20-40 \mathrm{~cm}: 1 \text { flake }\end{array}$ \\
\hline & MC070 & 35 & None \\
\hline & MC071 & 40 & $\begin{array}{l}0-20 \mathrm{~cm}: 1 \text { hammerstone, } 2 \text { flakes } \\
20-40 \mathrm{~cm}: 1 \text { flake }\end{array}$ \\
\hline & MC072 & 35 & None \\
\hline \multicolumn{4}{|l|}{$41 \mathrm{HI} 146$} \\
\hline & TN011 & 30 & None \\
\hline & TN012 & 20 & 0-20 cm: 6 flakes \\
\hline & MC011 & 40 & 0-20 cm: 1 flake \\
\hline & MC012 & 15 & 0-15 cm: 3 flakes, 2 burned rocks \\
\hline \multicolumn{4}{|l|}{ 41HI159 } \\
\hline & TN035 & 7 & None \\
\hline & TN036 & 20 & None \\
\hline & MC046 & 20 & 0-20 cm: 1 flake fragment, mussel shell fragments \\
\hline & MC047 & 20 & None \\
\hline & MC048 & 10 & None \\
\hline \multicolumn{4}{|l|}{$41 \mathrm{HI} 160$} \\
\hline & TN033 & 15 & None \\
\hline
\end{tabular}


Table A.1, continued

\begin{tabular}{|c|c|c|c|}
\hline Site & Shovel Test & Depth $(\mathrm{cm})$ & Materials Recovered \\
\hline & TN034 & 5 & None \\
\hline & MC044 & 30 & None \\
\hline & MC045 & 20 & None \\
\hline \multicolumn{4}{|l|}{$41 \mathrm{HI} 162$} \\
\hline & TN029 & 28 & None \\
\hline & TN030 & 0 & None \\
\hline & TN031 & 20 & None \\
\hline & TN032 & 5 & None \\
\hline & MC040 & 30 & None \\
\hline & MC041 & 30 & None \\
\hline & MC042 & 20 & None \\
\hline & MC043 & 10 & None \\
\hline \multicolumn{4}{|l|}{$41 \mathrm{HI} 169$} \\
\hline & TN021 & 40 & 0-20 cm: 3 flakes, 1 burned rock, 1 mussel shell \\
\hline & TN022 & 35 & $\begin{array}{l}0-20 \mathrm{~cm}: 4 \text { flakes, } 1 \text { gar scale } \\
20-35 \mathrm{~cm}: 2 \text { flakes }\end{array}$ \\
\hline & TN023 & 40 & 0-20 cm: 1 flake \\
\hline & TN024 & 30 & $0-20 \mathrm{~cm}: 1$ flake \\
\hline & MC033 & 30 & None \\
\hline & MC034 & 40 & $\begin{array}{l}0-20 \mathrm{~cm}: 5 \text { flakes, burned chert, } 1 \text { mussel shell fragment, } \\
\text { burned rocks } \\
20-40 \mathrm{~cm} \text { : mussel shell fragments }\end{array}$ \\
\hline & MC035 & 60 & $\begin{array}{l}0-20 \mathrm{~cm}: 2 \text { flakes, } 2 \text { mussel shell fragments } \\
20-40 \mathrm{~cm}: 5 \text { flakes, } 2 \text { mussel shell fragments } \\
40-60 \mathrm{~cm}: 12 \text { flakes }\end{array}$ \\
\hline & MC036 & 30 & 0-20 cm: 1 flake, 2 mussel shell fragments \\
\hline \multicolumn{4}{|l|}{ 41HI172 } \\
\hline & TN025 & 7 & None \\
\hline & TN026 & 10 & None \\
\hline & TN027 & 69 & $\begin{array}{l}0-20 \mathrm{~cm}: 1 \text { flake } \\
20-40 \mathrm{~cm}: 1 \text { flake } \\
60-69 \mathrm{~cm}: 1 \text { quartzite flake }\end{array}$ \\
\hline & TN028 & 60 & \begin{tabular}{|l|}
$0-20 \mathrm{~cm}: 1$ flake \\
$20-40 \mathrm{~cm}: 1$ flake \\
$40-60 \mathrm{~cm}: 4$ flakes \\
\end{tabular} \\
\hline & TN067 & 10 & None \\
\hline & TN068 & 15 & None \\
\hline & TN069 & 25 & None \\
\hline & MC036A & 20 & None \\
\hline & MC037 & 20 & None \\
\hline & MC038 & 85 & $\begin{array}{l}20-40 \mathrm{~cm}: 1 \text { flake } \\
40-60 \mathrm{~cm}: 2 \text { flakes } \\
60-80 \mathrm{~cm}: 3 \text { flakes, burned rocks } \\
\end{array}$ \\
\hline & MC039 & 20 & 0-20 cm: 2 flakes, 1 utilized flake \\
\hline & MC077 & 20 & None \\
\hline \multicolumn{4}{|l|}{$41 \mathrm{HI} 174$} \\
\hline & TN016 & 30 & None \\
\hline & TN017 & 35 & None \\
\hline & TN018 & 30 & None \\
\hline & TN019 & 10 & None \\
\hline & TN020 & 10 & None \\
\hline
\end{tabular}


Table A.1, continued

\begin{tabular}{|c|c|c|c|}
\hline Site & Shovel Test & Depth $(\mathrm{cm})$ & Materials Recovered \\
\hline & MC018 & 30 & None \\
\hline & MC019 & 5 & None \\
\hline & $\mathrm{MC020}$ & 5 & None \\
\hline & MC021 & 30 & None \\
\hline & MC022 & 5 & None \\
\hline \multicolumn{4}{|l|}{$41 \mathrm{HI} 175$} \\
\hline & TN013 & 15 & None \\
\hline & TN014 & 32 & None \\
\hline & TN015 & 100 & $80-100 \mathrm{~cm}: 1$ flake \\
\hline & TN064 & 7 & None \\
\hline & TN065 & 5 & None \\
\hline & TN066 & 50 & None \\
\hline & MC016 & 30 & 0-20 cm: 1 flake \\
\hline & MC017 & 65 & $20-40 \mathrm{~cm}: 1$ flake \\
\hline & MC073 & 10 & None \\
\hline & MC074 & 10 & None \\
\hline & MC075 & 10 & None \\
\hline & MC076 & 90 & None \\
\hline \multicolumn{4}{|l|}{$41 \mathrm{HI} 180$} \\
\hline & TN037 & 25 & 0-20 cm: 1 flake \\
\hline & TN038 & 30 & None \\
\hline & TN039 & 40 & None \\
\hline & MC049 & 50 & 0-20 cm: 1 flake \\
\hline & MC050 & 40 & None \\
\hline & MC051 & 30 & None \\
\hline \multicolumn{4}{|l|}{$41 \mathrm{HI} 260$} \\
\hline & TN001 & 58 & None \\
\hline & TN002 & 40 & None \\
\hline & TN003 & 30 & None \\
\hline & TN004 & 29 & None \\
\hline & MC001 & 70 & $40-60 \mathrm{~cm}: 1$ flake \\
\hline & MC002 & 20 & None \\
\hline & MC003 & & None \\
\hline & $\mathrm{MC004}$ & 30 & None \\
\hline \multicolumn{4}{|l|}{$41 \mathrm{HI} 311$} \\
\hline & TN050 & 10 & None \\
\hline & TN051 & 3 & 0-3 cm: 1 tested quartzite cobble \\
\hline & TN052 & 8 & None \\
\hline & MC062 & 10 & 0-10 cm: 2 flakes, 2 battered stones, 1 tested cobble \\
\hline & $\mathrm{MC} 063$ & 10 & None \\
\hline & MC064 & 10 & None \\
\hline \multicolumn{4}{|c|}{ Offsite Shovel Tests: } \\
\hline \multicolumn{4}{|c|}{ Survey Area 6} \\
\hline & TN044 & 20 & None \\
\hline & MC056 & 25 & None \\
\hline \multicolumn{4}{|c|}{ Survey Area 7} \\
\hline & TN045 & 33 & 0-20 cm: 1 core fragment \\
\hline & TN046 & 25 & None \\
\hline
\end{tabular}


Table A.1, continued

\begin{tabular}{c|l|c|l}
\hline Site & Shovel Test & Depth $(\mathrm{cm})$ & \\
\hline & TN047 & 20 & None \\
\hline & MC057 & 30 & None \\
\hline & MC058 & 30 & None \\
\hline & MC059 & 30 & None \\
\hline Survey Area 2 & & & \\
\hline & TN048 & 32 & None \\
\hline & TN049 & 24 & None \\
\hline & TN053 & 2 & None \\
\hline & MC060 & 40 & 0-20: 1 chain link \\
\hline & MC061 & 55 & None \\
\hline & MC065 & 10 & None \\
\hline & & & \\
\hline Survey Area 9 & TN054 & 40 & None \\
\hline & & & \\
\hline & TN055 & 15 & None \\
\hline
\end{tabular}



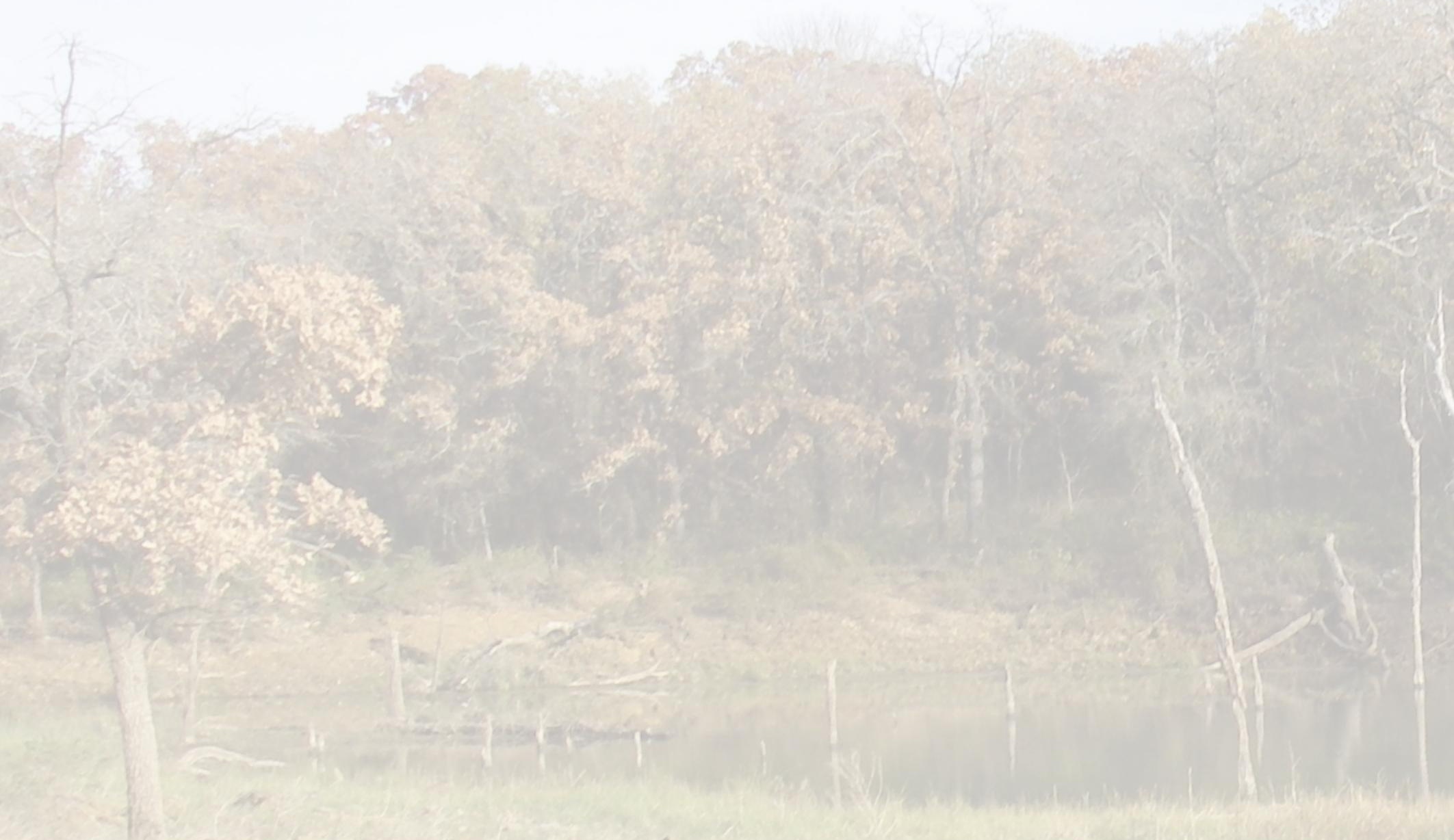<smiles>C1CC1</smiles>

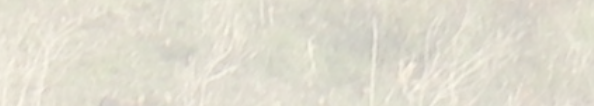

